\title{
The Protective Effect of Ocimum Basilicum on the Induced Diabetic Colon of Adult Male Albino Rats: A Histological, Histochemical and Immunohistochemical Study
}

Original
Article

\author{
Maha El-Sayed Soliman, Amira Fahmy Ali, Nadia Said Badawy khair and \\ Reham Abdulla Mahmoud
}

Department of Histology and Cell Biology, Faculty of Medicine, Menoufia University

\section{ABSTRACT}

Introduction: Diabetes Mellitusi is a common endocrine and metabolic disease. It ischaracterized by hyperglycemia and abnormal metabolism of the lipid, carbohydrate, and protein that are caused bydeficiency of insulin or defective insulin action or both. Today, it is considered as one of the major health problems in the world. Ocimum basilicum (Basil) is one of the most widely grownpopular herbs in the world. It contains a large number of phytochemicals which have many significant health and nutritionalbenefits. It belongs to Lamiaceae (Mint family)and possesses marked anti-hyperlipidemic, anticancer and antioxidant activity.

Objective: The aim of this work is to evaluate the possible protective effect of Ocimum basilicum administration on the induceddiabetic colon of adult male albino rats.

Materials and Methods: Sixty adult male albino rats were used in the present study. They were divided into four groups, Group I (control group), Group II (ocimum basilicum received group), Group III (diabetic group) and Group IV (diabetic with ocimum basilicum group). After four weeks, the animals from all groups were anaesthetized and the blood samples were collected for biochemical study. The colon was dissected and the specimens were subjected to histological, histochemical, immunohistochemical and scanning electron microscopic studies.

Results: Diabetic colon revealed a significant increase in the depth of intestinal crypts and number of goblet cells with marked biochemical and histological alterationsas increase in plasma level of MDA, shedding of the surface mucosa and small size Aeurbach's myenteric plexus. Administration of Ocimum basilicum in rats with diabetes mellitus has ameliorating effect on the histological, biochemical and morphometric abnormalities of the colonic tissue.

Conclusion: Ocimum basilicum has a protective effect on the histological, biochemical and morphometric changes of the colon of diabetic rats. It has also a protective effect on the intestinal myenteric nerve plexus.

Received: 25 January 2019, Accepted: 16 March 2019

Key Words: Colon, diabetes, goblet cells, ocimum basilicum.

Corresponding Author: Nadia Said Badawy khair, MD, Histology Department, Faculty of Medicine, Menuofiya University, Menuofiya, Egypt, Tel.: +20482286683, E-mail: amarsmile2007@yahoo.com

ISSN: $1110-0559$, Vol. 42, No. 3

\section{INTRODUCTION}

Diabetes Mellitus is one of the top diseases of the endocrine pancreas. It is characterized by hyperglycemia and abnormal metabolism of the carbohydrate, proteinandlipids. Itis caused by deficiency of insulin or defective insulin action or both ${ }^{[1]}$ which contributes to generationof free radicals ${ }^{[2]}$.

Diabetes mellitus is a complex and multifarious group of disorders.Today,it is considered as one of the major health problems in the world.There are about 400 million people and counting worldwide were diagnosed with the disease $^{[3]}$.

There are two types of diabetes mellitus, type 1 (insulin dependent) and type 2 (non-insulin dependent). All types of diabetes are characterized by vascular damage of small blood vessels. This damage affects many organs like the kidney (nephropathy), peripheral nerves (neuropathy) and retina (retinopathy). About $76 \%$ of diabetic outpatients have gastrointestinal symptoms such as gastroparesis, nausea, vomiting, diarrhea, abdominal pain and constipation, which may affect the patient's quality life negatively ${ }^{[4]}$. Diabeticneuropathy plays important role in their pathogenesis ${ }^{[5]}$.

Gastrointestinal diabetic manifestations are usually due to neuropathy affecting the enteric nervous system (ENS), which is present in the wall of the gastrointestinal tube ${ }^{[9]}$. ENS is a part of the autonomic nervous system and is responsible for autonomic reflexes of the gastrointestinal tract as absorption and motility. It consists of two main cell types, neurons and enteric glial cells (EGCs) $)^{[6]}$.

Alloxan (2, 4, 5, 6-tetraoxypyrimidine; 2, 4, 5, 6- pyrimidinetetrone) is an oxygenated pyrimidine derivative which is present as alloxan monohydrate in aqueous solution. It is commonly used to cause diabetes 
in experimental animals such as rats, mice, rabbits and dogs through selective necrosis of the $\beta$ - cells of pancreatic islets $^{[7]}$.

Ocimum basilicum (Basil) is one of the most widely grownpopular herbs in the world. It contains a large number of phytochemicals which have many significant nutritional and health benefits ${ }^{[8]}$. It belongs to Lamiaceae (Mint family ${ }^{[9]}$. Basil possesses marked anti-hyperlipidemic effect $^{[10]}$, anticancer activity ${ }^{[11]}$ and antioxidant activity ${ }^{[12]}$.

Although a large number of studies were done to study the effects of natural plants on diabetes, induced by alloxan in many animal organs, few number of studies have been carried outto verify the mechanism by which colonic manifestations occur in diabetic models. Therefore, this study aimed to evaluate the effect of Ocimum basilicum administration on the colon of rats suffering from diabetes using histological, histochemical and immunohistochemical studies.

\section{MATERIALSAND METHODS}

\section{Drugs}

- Alloxan: It is available as alloxan monohydrate powder manufactured by Sigma Pharm Company. It dissolved in distilled water and given by intraperitoneal injection.

- Ocimum basilicum: It is an essential oil and it is purchased from a supermarket.

\section{Animals}

Sixty adult male albino rats, each one weighing180$200 \mathrm{gm}$, were used in this study. They were housedat room temperature in stainless steel cages. They had free access to laboratory rat chow diet and water ad-libitum. Stricthygieneand care were taken to keep a healthy andnormal environment for the rats. The general conditions and behavior of the animals were noticed. Animal treatment was according to ethical protocol that was approved by the Ethical Committee of Menoufia faculty of medicine.

\section{Experimental procedure}

The rats were randomly divided into four groups, each included 15 animals.

Group I (negative control group): The animals of this group were provided with distilled water orally for four weeks.

Group II (positive control group): The animals received ocimum basilicum essential oil at a dose of $400 \mathrm{ml} / \mathrm{kg} / \mathrm{d}$ orally for 4 weeks ${ }^{[13]}$.

Group III(diabetic group): Induction of diabetes was done by a single intraperitoneal injection of $150 \mathrm{mg} / \mathrm{kg}$ of alloxan dissolved in distilled water ${ }^{[13 \& 14]}$ and keep up to the end of experiment.

Group IV (diabetic with ocimum basilicum group): They received a single intraperitoneal injection of $150 \mathrm{mg} / \mathrm{kg}$ of alloxan for induction of diabetes and ocimum basilicum essential oil at a dose of $400 \mathrm{ml} / \mathrm{kg} / \mathrm{d}$ for 4 weeks $^{[14]}$.

\section{Induction of diabetes}

This was done by single intraperitoneal injection of animals with aqueous solution of alloxan monohydrate which was freshly prepared at a dose of $150 \mathrm{mg} / \mathrm{kg}$ body weight. $10 \%$ dextrose was given orally after administration of alloxan to avoid the hypoglycemia that might appear immediately after alloxan injection. The blood glucoselevels were observed $20 \mathrm{~h}$ after administration of alloxan. Fasting blood glucose levels were measured daily for 3 days. Blood glucose levels more than $126 \mathrm{mg} / \mathrm{dL}$, were considered diabetic ${ }^{[14]}$.

After four weeks, ether inhalation was used to anaesthetize the animals from all groups. Blood samples were collected into heparin coated tubes and centrifuged at $2200 \mathrm{~g}$ for $10 \mathrm{~min}$. Plasma samples were stored at -20 c for biochemical study. A median abdominal incision was achieved to expose the intestine and the distal $5 \mathrm{~cm}$ of the colon was excised and cleaned by normal saline. The specimens were subjected to histological, histochemical ,immunohistochemical and scanning electron microscopic studies.

\section{I- Biochemical study}

All biochemical studies were done in the central laboratory, faculty of medicine, Menoufia University.

\section{Blood glucose level}

Plasma glucose levels were estimated using a commercial Glucose Colorimetric Assay Kit (Cayman Chemical Company, Ann Arbor, MI, USA).

\section{Oxidative stress markers}

\section{a-Estimation of malondialdehyde (MDA)}

Malondialdehyde (MDA) is considered as indirect indicator for lipid peroxidation ${ }^{[15]}$. Plasma MDA level was measured by the following procedure in which $0.5 \mathrm{ml}$ of plasma was shaken with $2.5 \mathrm{ml}$ of $20 \%$ trichloroacetic acid (TCA) and $1 \mathrm{ml}$ of $0.6 \%$ thiobarbituric acid (TBA) then the mixture was warmed by boiling water bath followed by rapid cooling with cold water. The mixture was centrifuged at $3000 \mathrm{rpm}$ for $10 \mathrm{~min}$ then it was shaken into a $4 \mathrm{ml}$ of nbutyl-alcohol layer and MDA was determined by spectrophotometer at the absorbance $532 \mathrm{~nm}$ against butanol. The results were expressed as $\mu \mathrm{mol} / \mathrm{ml}$ plasma.

\section{B-Estimation of superoxide dismutase (SOD)}

Determination of plasma SOD was done by a modified spectrophotometeric assay method ${ }^{[16]}$. Briefly, $1.35 \mathrm{ml}$ of double distilled water, $50 \mu \mathrm{l}$ of sodium pyrophosphate buffer (PH 8.3), $0.1 \mathrm{ml}$ of phenazinemethosulphate (PMS) and $0.3 \mathrm{ml}$ of nitrobluetetrazolium (NBT) were mixed. $0.2 \mathrm{ml}$ of NADH solution is thenaddedto it to initiate the reaction. After incubation at $39{ }^{\circ} \mathrm{C}$ for $90 \mathrm{~s}$, the reaction was terminated by adding $1 \mathrm{ml}$ of glacial acetic acid. $4 \mathrm{ml}$ 
of n-butanol was added and the mixture was centrifuged at $4000 \mathrm{rpm}$ for $10 \mathrm{~min}$ and the absorbance of the upper butanol layer recorded at $560 \mathrm{~nm}$. One unit of SOD activity is defined as that amount of enzyme reaction, which inhibits the rate of reactions, by $50 \%$ in 1 min under assay conditions.

\section{C-Estimation of catalase (CAT)}

This assay employs the quantitative sandwich enzyme immunoassay technique by ELISA kit. Antibody specific for CAT has been pre-coated onto a micro-plate ${ }^{[17]}$.

\section{II- Histological study}

Tissue samples were fixed in $10 \%$ formal saline, washed and processed for paraffin sections. Sections of about 5-6 $\mu \mathrm{m}$ thickness were obtained and stained with hematoxylin and eosin (Hx\&E) to show the histological details\&Mallory's trichrome stain to detect the collagen fibers $^{[18]}$.

\section{III-Scanning electron microscopic study}

The tissues were cut into small pieces, fixed in buffered glutraldehyde solution and processed for examination, using Philips Scanning Electron Microscope in Tanta EM unit at Faculty of medicine, Tanta university.

\section{IV-Histochemical study}

The specimens were processed and stained with Alcian blue for detection of mucopolysaccharides ${ }^{[19]}$.

\section{V-Immunohistochemical study}

\section{Glial fibrillary acidic protein immunostaining (GFAP)}

Paraffin sections were deparaffinized and rehydrated. The activity of endogenous peroxidase was blocked with $0.05 \%$ hydrogen peroxide in absolute alcohol for $45 \mathrm{~min}$. The slides were placed in phosphate buffered saline (PBS) for $7 \mathrm{~min}$ to expose the antigen sites, sections were put in citrate buffer for $10 \mathrm{~min}$ in a microwave. The slides were incubated in bovine serum albumin dissolved for $30 \mathrm{~min}$ in PBS to prevent nonspecific background staining. Then,the sections were incubated with the primary antibodies (except for the negative control)at room temperature for $90 \mathrm{~min}$. GFAP antibody was added to the sections. The slides were rinsed with PBS and then incubated for 60 min with anti-mouse immunoglobulins, conjugated to a peroxidase-labelled dextran polymer ${ }^{[20]}$. Negative control serial sections were processed by replacing the primary antibody with PBS, with all other steps performed in the same manner. Normal brain was used as a positive control for GFAP ${ }^{[20]}$.

\section{Inducible nitric oxide synthase immunostaining (i NOS)}

Paraffin sections were deparaffinized and rehydrated. Nonspecific endogenous peroxidase activity was blocked by treatment with $0.9 \%$ hydrogen peroxide in absolute methanol for 10 min and then rinsed briefly in PBS. Then, the slides were incubated witha blocking solution $(0.1$ Mphosphate-buffered saline containing $0.1 \%$ Triton X-100 and $2 \%$ normal goat serum) for 2 hrto block nonspecific binding. Sections were incubated with inducible Nitric oxide synthase (iNOS) rabbit polyclonal antibody (Product GTX15323; dilution 1:100, Gene Tex, USA)at room temperature for an hour. Control sections included buffer alone or nonspecific purifiedrabbit IgG. Then, abiotinylated goat anti-rabbit secondary antibody and the avidin-biotin-peroxidase complex (Vectastain Elite $\mathrm{ABC}$ kit, Vector Laboratories) were added to the sections. Color wasobtained by addition of diaminobenzidine as chromogen for 5-15 minutes. Negativecontrol sections included buffer alone or nonspecific purified rabbit IgG. Human liver tissue was used as a positive control for iNOS $^{[21]}$.

\section{VI-Morphometric study and Statistical analysis}

The depth of the intestinal crypts, the number of goblet cells were measured in $\mathrm{H} \& \mathrm{E}$ stained sections while the intensity of iNOS immunostaining and the intensity of GFAP immunostaining were measured in immunostained sections, using the objective lens of magnification 40 (x 400) of light microscopy. From each rat, 10 non-overlapping microscopic fields were used. This was performed using the interactive measuring menu of image analyzer (LeciaQwin 500 image analyzer computersystem,England) in Anatomy Department, Faculty of Medicine, Menoufia University, Egypt.

The biochemical and morphometric results were analyzed and compared by student's t-test. The p-value was used to test the significant change in each parameter in the experimental animals in comparison with the control group. The data collected were tabulated as mean $\pm \mathrm{SD}$ and analyzed using statistical package for the Social Science Software (SPSS) software (version 17.0 on an IBM compatible computer; SPSS Inc., Chicago, Illinois, USA). $P$ value was set at $0.05, P>0.05$ non-significant, $P$-value $<0.05$ significant and $P$-value $<0.001$ highly significant ${ }^{[22]}$.

\section{RESULTS}

\section{Biochemical results}

\section{Blood glucose level}

Statistical analysis for blood glucose level, showed a non-significant $(P>0.05)$ decrease in the mean value between group 1 and II and a highly significant increase $(p<0.001)$ in the diabetic rats (group III) compared with the control (group I). However, there was a highly significant decrease $(p<0.001)$ in the blood glucose level on administration of $\mathrm{O}$. basilicum to diabetic rats (group IV) compared with the diabeticgroup (group III) (Table 1)

Data in (Table 2) showed a non-significant $(P>0.05)$ decrease in the mean value of plasma level of MDA (the marker of lipid peroxidation) between group 1 and II. The diabeticanimals (group III) exhibited a highly significant 
increase $(p<0.001)$ in the plasma level of MDA compared with the animals of control group (Histogram 1). Highly significant decrease $(p<0.001)$ in the activities of the antioxidant enzymes, superoxide dismutase (SOD) and catalase (CAT) was observed in the rats of this group. On the other hand, rats of diabetic $+\mathrm{O}$. basilicum (group IV) showed a decrease in MDA and a dramatic increase in the antioxidant status (SOD, CAT) (Histogram 1).

\section{Histological results}

In H\& E sections, colon of control animals (group I \& II) showed the normal histological architecture of the rat colon and no difference between them. The wall of the colon was formed of mucosa, submucosa, musculosa and serosa (Figure 1). The mucosa of colon showed intact surface lined with columnar epithelium with acidophilic cytoplasm and basal basophilic oval nuclei. Crypts appeared straight tubular in shape with narrow openings (Figure 2). The crypts were lined by simple columnar epithelium that had basal oval vesicular nuclei and prominent nucleoli. Goblet cells are flask shaped with vacuolated cytoplasm and basal flattened nuclei (Figure 3). The musculosa consists of inner circular and outer longitudinal smooth muscle layers (Figure 1). The Aeurbach's plexus was present between these two layers of the musculosa. The plexus formed of numerous nerve cells, numerous enteric glial cells (EGCs) and network of unmyelinated nerve fibers (Figure 4).

The colon sections of the diabetic group (group III) showed severe disturbed crypts, which lined with smallsized cells having pyknotic nuclei. In addition, shedding of surface epithelium in the lumen was also present in some parts (Figures 5-7).An apparent increase in the goblet cells with cellular infiltrations in the lamina propria and separation of the muscle layers of musculosa were seen (Figure 6).

The lumen of crypts was widening, and some crypts were lined with columnar cells with faint nuclei while other cells had small pyknotic nuclei. The goblet cells showed increase in their size and fusion of their cytoplasm together (Figure 7). Aeurbach's plexus was decreased in size with an apparent decrease in the number of nerve cells and enteric glial cells (EGCs), compared with the control group (Figure 8).

On the other side, examination of group IV (diabetic $+\mathrm{O}$. basilicum group) revealed marked reduction of the pathological changes of the colon. Nearly mucosa, crypts, submucosa and musculosa normal appearing more or less as in control group. However, cellular infiltration between the crypts (Figure 9) and some fused goblet cells (Figure 10) were still present. Intact surface columnar epithelium and nearly normal shape of the crypts (Figure 10) with large pale vesicular nuclei of its lining epithelial (Figure 11) were also seen. A more or less normal shaped Aeurbach's plexus in the musculosa with an apparent increase in the number as well as size of nerve cells and EGCs in comparison with the diabetic group (group III) was observed (Figure 12).
Regarding to the Mallory Trichrome stained colon sections of control groups (group I \& II), it showed presence of mild amount of collagen fibers (appeared as tinge of blue colored strips) in the corium and submucosa (Figure 13). However, in diabetic group (group III) there was a moderate amount of collagen fibers in the corium and in the submucosa (Figure 14). While diabetic $+\mathrm{O}$. basilicum (group IV) showed mild amount of collagen fibers more or less as in control group (Figure15).

Examination of control animals (group I\&II) by scanning electron microscope revealed normal openings of the intestinal crypts with intact mucosal surface. Large number of empty and distended goblet cells with mucous extruded on the surface were also seen (Figures 16,17). Velvety appearance of the mucosal surface was observed (Figure 18). Diabetic animals (group III) showed widening of the openings of the crypts with presence of extruded mucous (Figure 19). Some areas showed large mucosal fissures with appearance and exfoliation of collagen fibers to the surface with loss, desquamation and ulceration of the mucosal surface lining epithelium (Figures 20,21). Group IV (diabetic treated with ocimum basilicum) showed nearly normal shaped mucosal crypts with wide openings, the lumen of some crypts was obstructed by secreted mucous (Figure 22).However, intact mucosal surface with normal crypt openings and intact goblet cells were also seen (Figures 22\&23).

\section{Histochemical staining}

Alcian blue staining of sections of colon from the control groups showed mild positive reaction of goblet cells of the intestinal crypts (Figure 24). However, strong positive reaction of these cells was seen in diabetic group (Figure 25), while, the diabetic + O. basilicum (group IV) showed moderate positive reaction of goblet cells of the intestinal crypts (Figure 26).

\section{Immunohistochemicalstudy}

Glial fibrillary acidic protein (GFAP): sectionsof the colon of control groups showed large Aeurbach's plexus with large number of enteric glial cells (EGCs) which exhibited strong positive immunoreactions in their cytoplasm and their processes and GFAP negative nerve cells (Figure 27). Diabetic group showed small sized myenteric plexus with GFAP positive EGCs which had weak positive immunoreaction surrounding immunenegative nerve cells (Figure 28). Diabetic + O. basilicum group showed moderate positive GFAP immune- reaction in EGCs compared with the diabetic group (Figure 29).

Inducible nitric oxidase synthase (iNOS): immunoreaction of iNOS was weak positive in colonic mucosa from control rats (Figure 30). However, colonic sections from diabetic group revealed strong positive immmunostaining for iNOS in the mucosa (Figure 31). While moderate positive immune reaction of iNOS in colonic sections of diabetic $+\mathrm{O}$. basilicum group was found (Figure 32), compared with the control group. 


\section{Morphometric results}

Data in (Table 3) showed that diabetic (group III) exhibited a highly significant increase $(P<0.001)$ in the depth of intestinal crypts and number of the goblet cells in comparison with the control group. Rats of diabetic + O. basilicum group (group IV) showed a highly significant decrease $(P<0.001)$ in comparison with the diabetic group (Histogram 2).

Data in (Table 4) demonstrated thatdiabetic (group III) exhibited a highly significant decrease $(P<0.001)$ inthe intensity of GFAP immunereaction in the colonic tissue of rats when compared with the control group. While, on administration ofO. basilicum to the diabetic rats (group IV), they exhibited a highly significantincrease $(P<0.001)$ in the intensity of GFAPimmunereaction in comparison with the diabetic group.

In addition, (Table 4) also showed that diabetic (group III) exhibited a highly significant increase $(P<0.001)$ in the intensity of iNOS immunereaction in the colonic tissue of rats when compared with the control group. However, rats of the diabetic + O. basilicum group (group IV) showed a highly significant decrease $(P<0.001)$ in the intensity of iNOS immunereaction in comparison with the diabetic group.

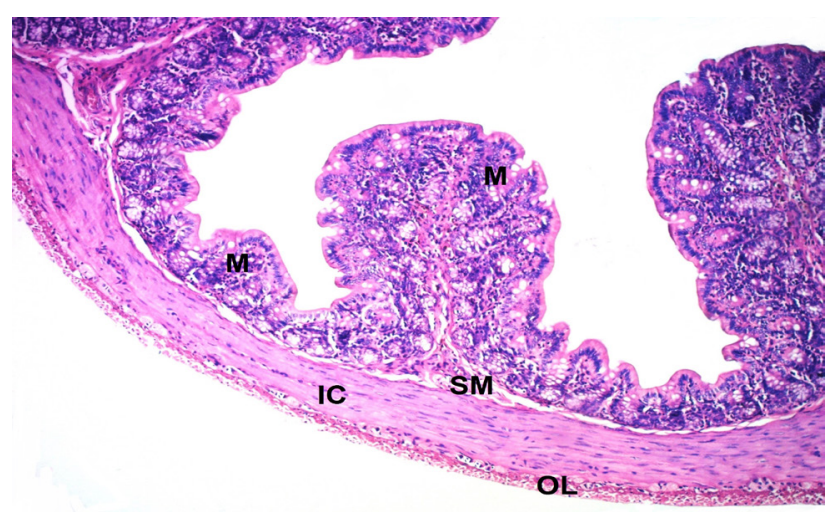

Fig. 1: A photomicrograph of a section of the colon from a control rat (group I) showing normal shaped mucosa (M), submucosa (SM) and musculosa formed of inner circular (IC) and outer longitudinal (OL) smooth muscle layers. (H \&E x 100)

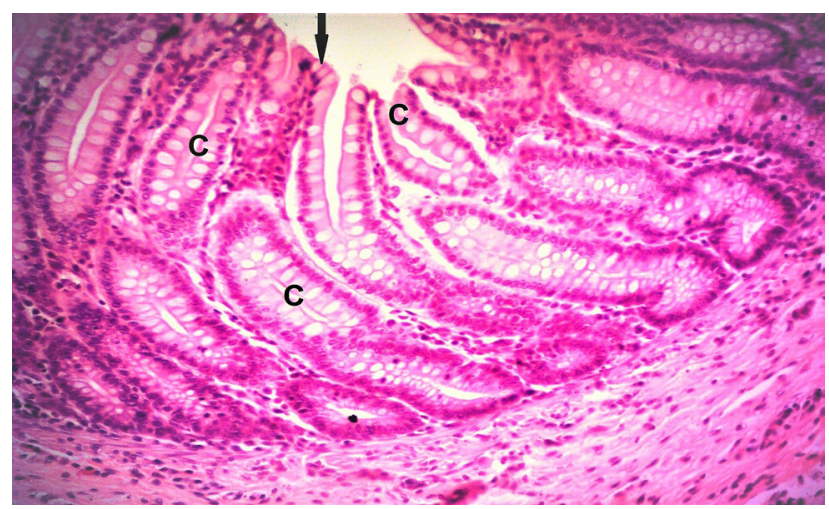

Fig. 2: A photomicrograph of a section of the colon from a control rat (group I)showing intact surface columnar epithelium with acidophilic cytoplasm and basal oval nuclei (arrow) and normal shaped crypts (C) with narrow openings. $\quad$ (H\&E x 200)

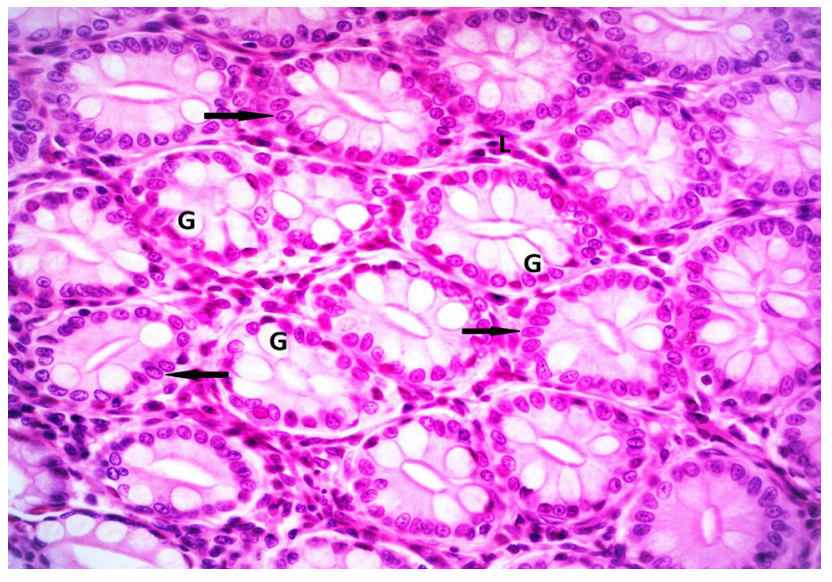

Fig. 3: A photomicrograph of a transverse section of the crypts of the colon from a control rat (group I) showing simple columnar epithelium with basal oval vesicular nuclei and prominent nucleoli (arrows). Goblet cells are flask shaped with vacuolated cytoplasm and basal flattened nuclei $(G)$. Notice, the connective tissue of lamina propria in between crypts (L). (H \& E x 400)

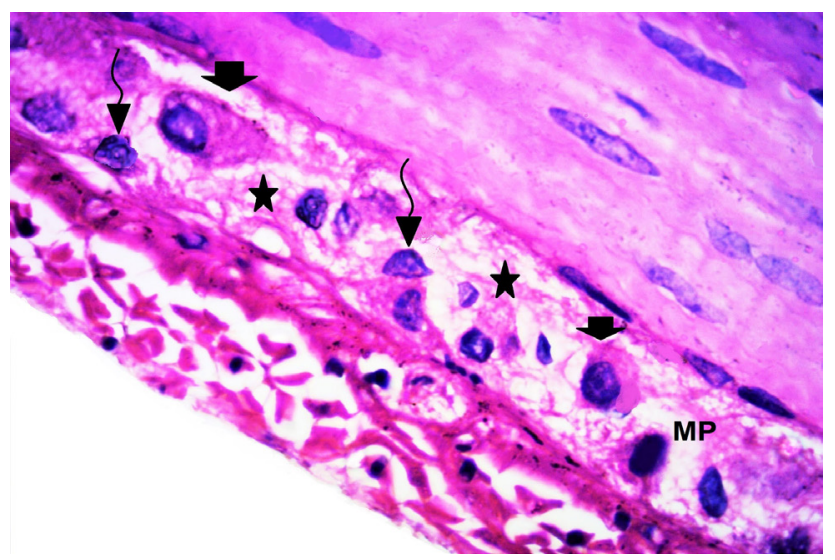

Fig. 4: A photomicrograph of a section of a colon from a control rat (group I) showing a well defined myenteric plexus (MP) present between the two layers of the musculosa. The plexus consists of numerous nerve cells (arrows), numerous enteric glial cells (curved arrows) and a network of unmyelinated nerve fibers (star). (H \&E x 1000)

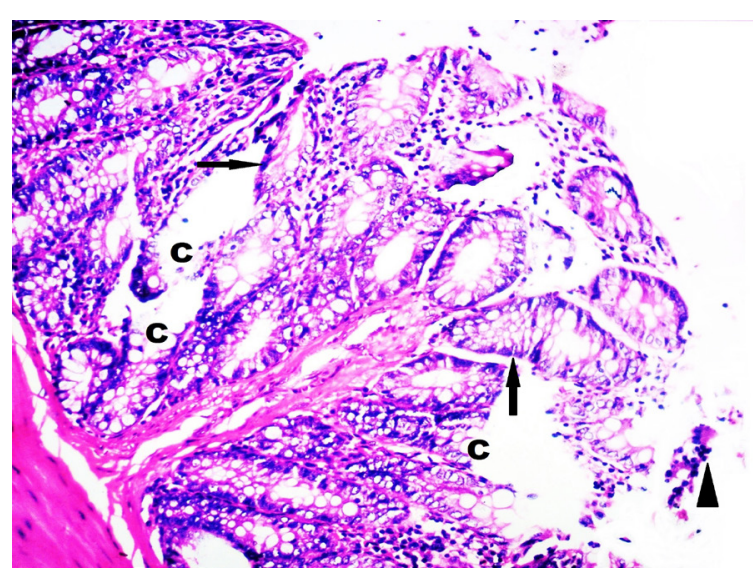

Fig. 5: A photomicrograph of a section of a colon from a diabetic rat (group III) showing complete disturbed crypts (C) lined with small sized cells having small deeply stained nuclei ( arrows). Loss of surface lining epithelium and their shedding in the lumen (arrow head) is also seen.(H \& E x 200) 


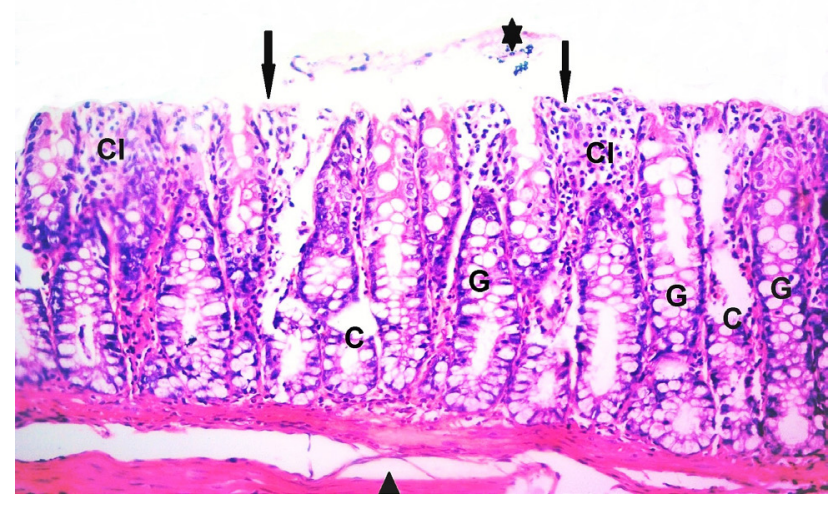

Fig. 6: A photomicrograph of a section of a colon from diabetic rat (group III) showingloss of surface epithelium ( arrow) with exfoliated cells in the lumen (star), an apparent increase in goblet cells $(\mathrm{G})$ and complete distortion of some crypts ( C). Note, the separation of muscle layers (arrowhead) and cellular infiltrations in the lamina propria(CI). (H \& E x 200)

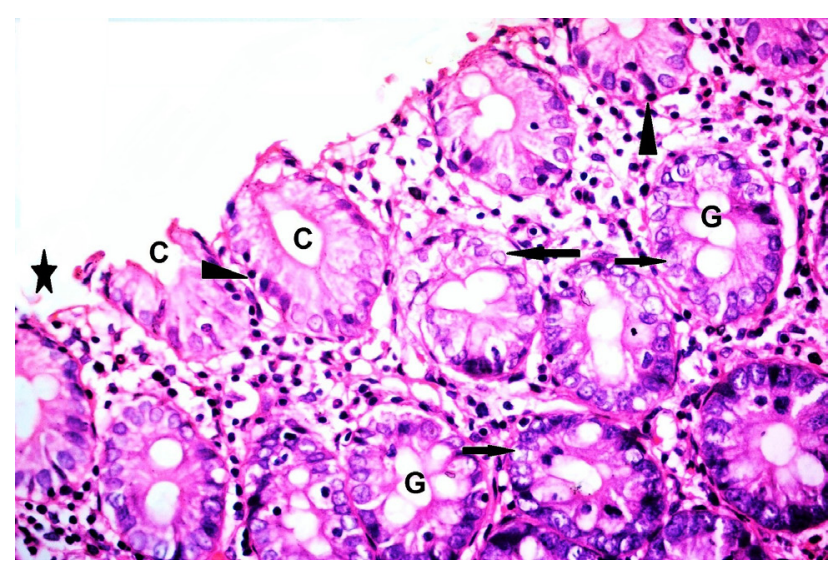

Fig. 7: A photomicrograph of a section of a colon from a diabetic rat (group III)showing widening of the lumen of crypts (C). The crypts are lined by columnar cells with faint nuclei (arrows)and others having small pyknotic nuclei (arrow head). The goblet cells are enlarged and fused (G). Note, the surface epithelial mucosal loss (star). (H\& E x 400)

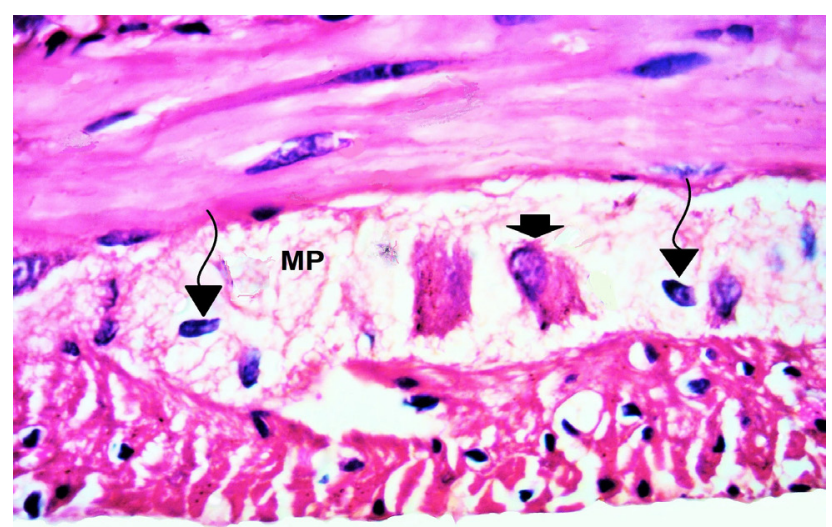

Fig. 8: A photomicrograph of a section of a colon from a diabetic rat (group III) showing small sized myenteric plexus (MP) having few nerve cells (arrow) and few enteric glial cells (curved arrows). (H\& E x 1000)
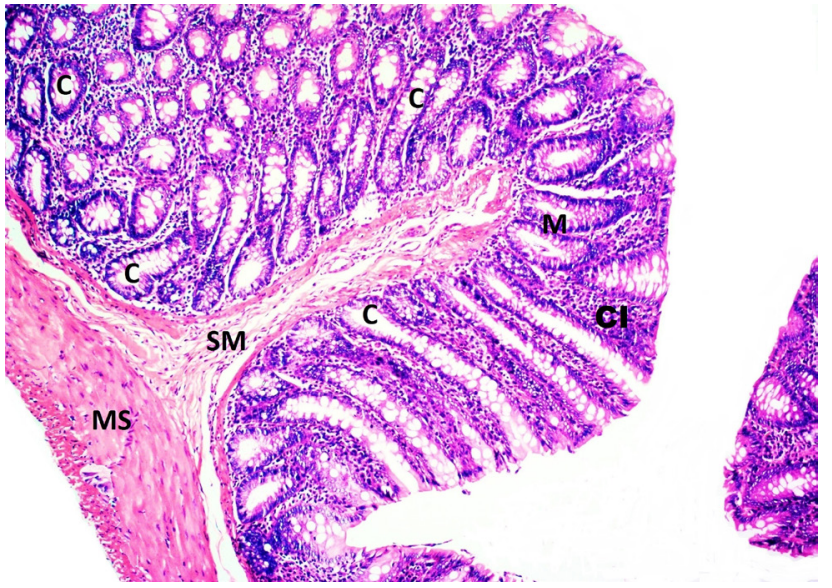

Fig. 9: A photomicrograph of a section of a colon from a diabetic rat treated with ocimum basilicum (group IV)showing nearly normal appearing mucosa $(\mathrm{M})$, crypts $(\mathrm{C})$, submucosa $(\mathrm{SM})$ and musculosa (MS). Note presence of cellular infiltration(CI). (H \&E x100)

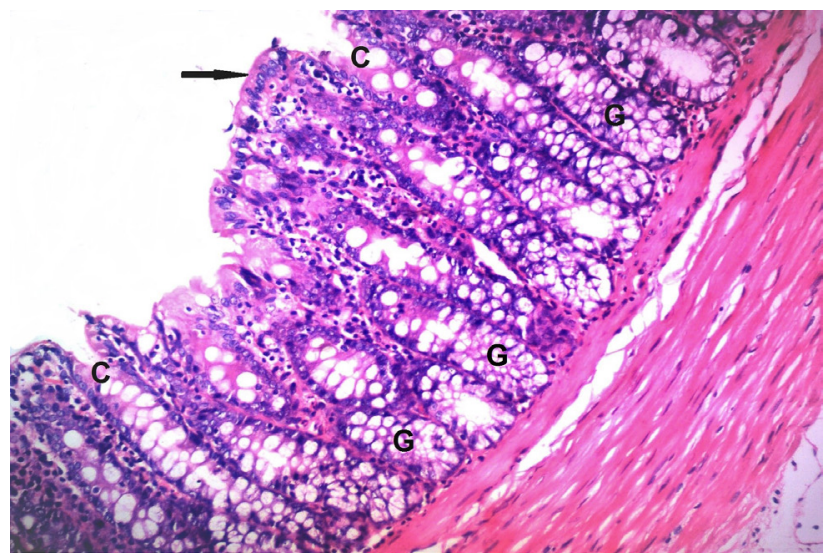

Fig. 10: A photomicrograph of a section of a colon from a diabetic rat treated with ocimum basilicum(group IV) showing intact surface columnar epithelium (arrow), some fused goblet cells $(G)$. Nearly normal shape of the crypts (C) is also present. (H \& E x 200)

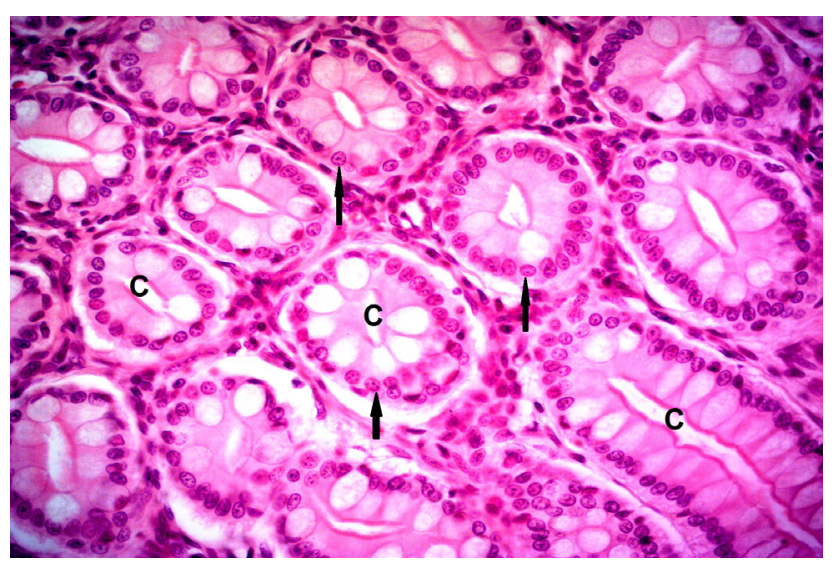

Fig. 11: A photomicrograph of a section of a colon from a diabetic rat treated with ocimum basilicum(group IV) showing normal crypts shape (C)with large pale vesicular nuclei of its epithelial lining (arrows). (H\& E x 400) 


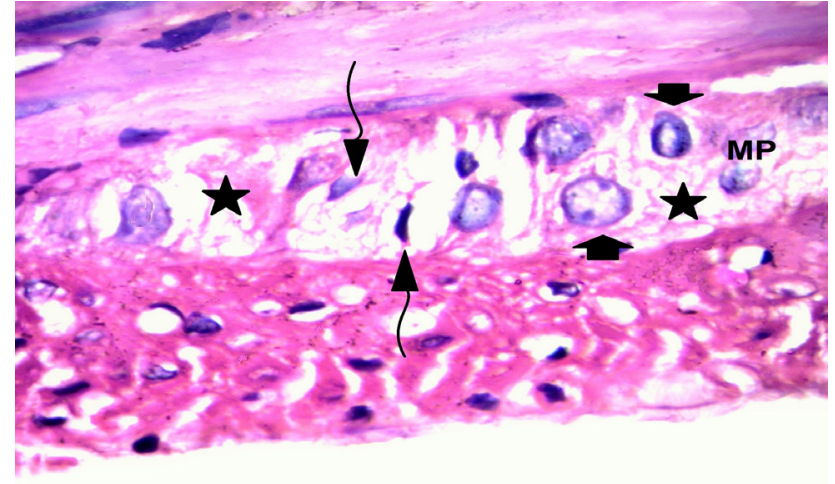

Fig. 12: A photomicrograph of a section of a colon from a diabetic rat treated with ocimum basilicum(group IV) showing a nearly normal shaped myenteric plexus (MP) in the musculosa, with apparent increase in the number and size of nerve cells (arrows), enteric glial cells (curved arrow) and network of unmyelinated nerve fibers (star). (H\& E x 1000)

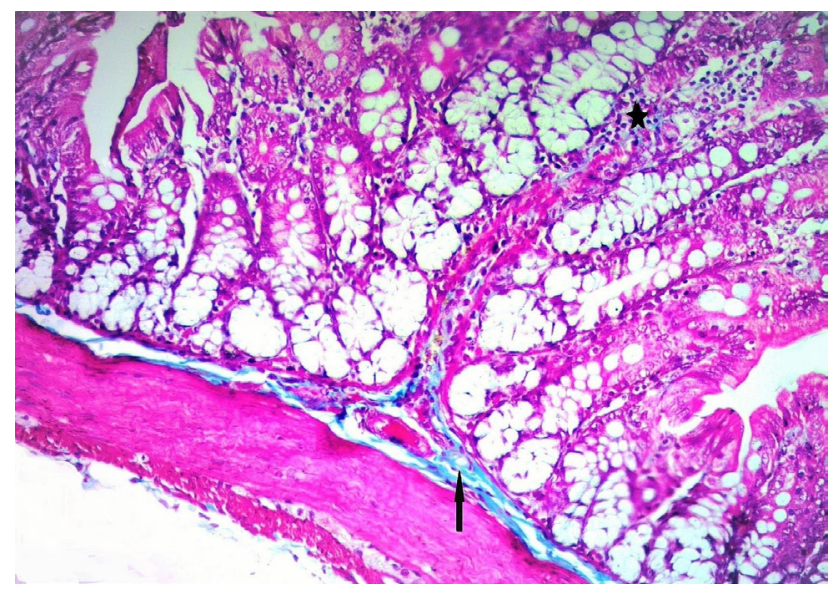

Fig.13: A photomicrograph of a section of a colon from a control rat (group I) showing mild amount of collagen fibers(appeared as tinge of blue colored strips) in the submucosa (arrow) and lamina propria (stars). (Mallory trichrome x 200)

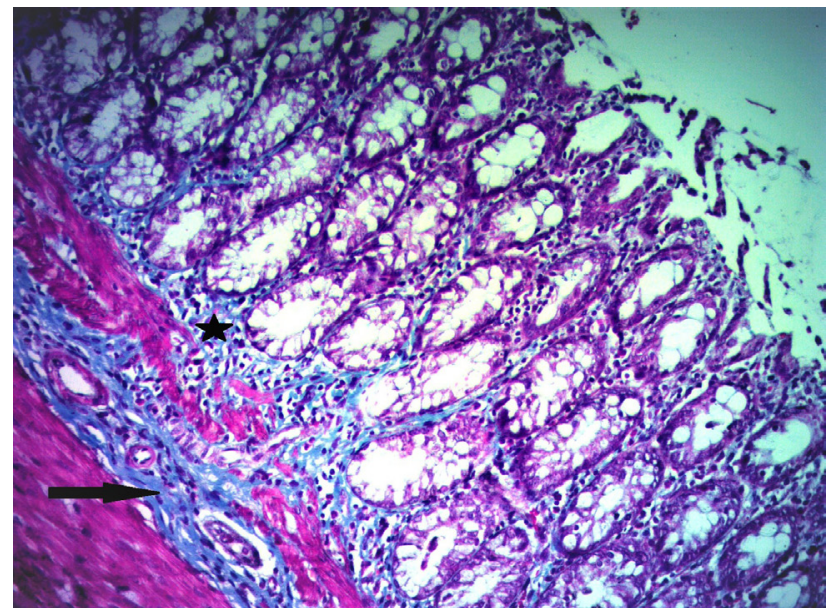

Fig. 14: A photomicrograph of a section of a colon from a diabetic rat (group III) showing moderate amount of collagen fibers in the lamina propria, in between the crypts (star) and in the submucosa (arrow). (Mallory trichrome x 200)

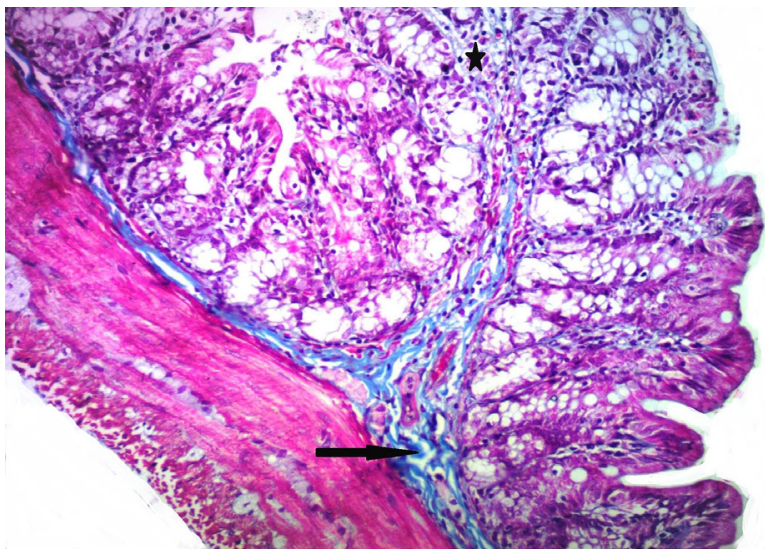

Fig. 15: A photomicrograph of a section of a colon from a diabetic rat treated with ocimum basilicum (group IV) showing mild amount of collagen fibers in the lamina propria (star) and in the submucosa (arrow). (Mallory trichrome x 200)

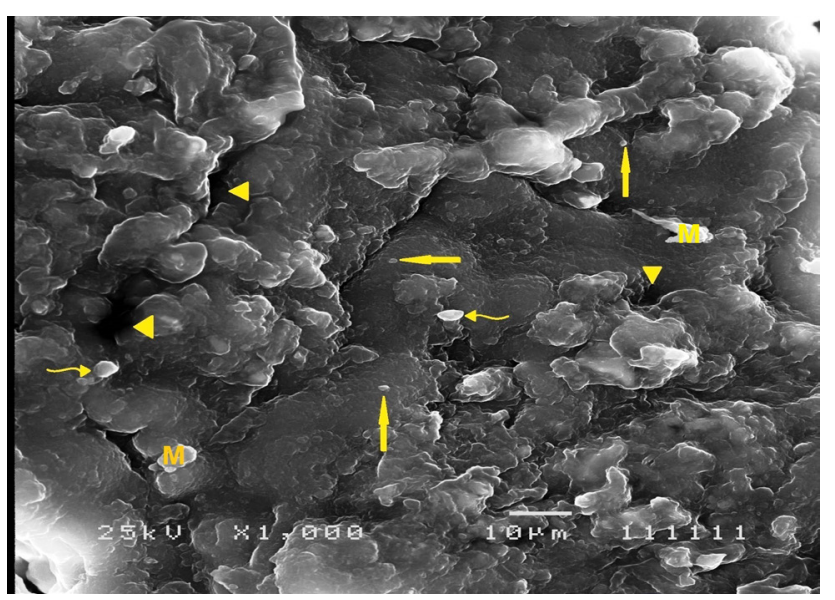

Fig.16: A scanning electron micrograph of a colon from a control rat (group I) showing normal shaped mucosal crypts opening (arrow head) with intact mucosal surface, numerous distended (curved arrows) and empty goblet cells (arrows) are also seen. Notice: the extruded mucous (M) on the surface of the mucosa. (SEM x 1000)

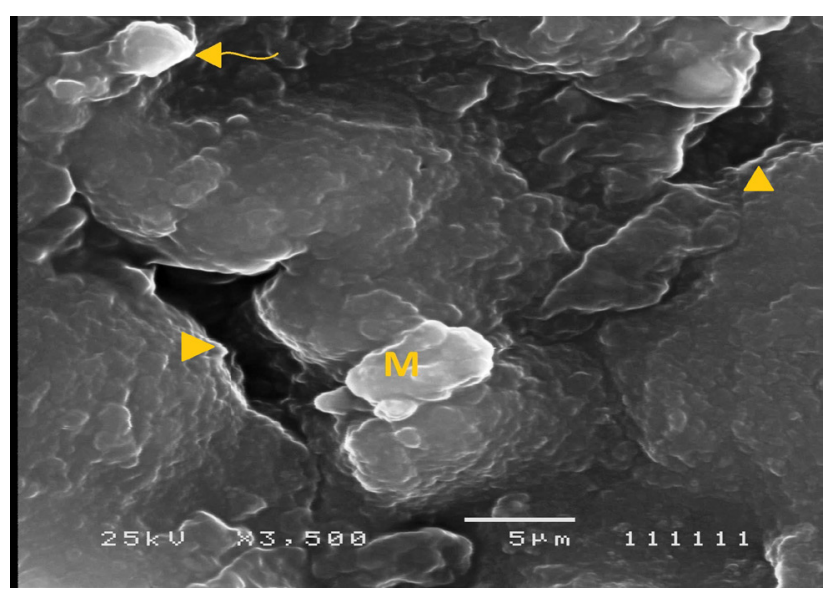

Fig. 17: A higher magnification of the previous picture showing opening of the mucosal crypts (arrow head) with intact mucosal surface . Notice, distended goblet cells (curved arrow) and extruded mucous (M) on the surface of mucosa. (SEM x 3500) 


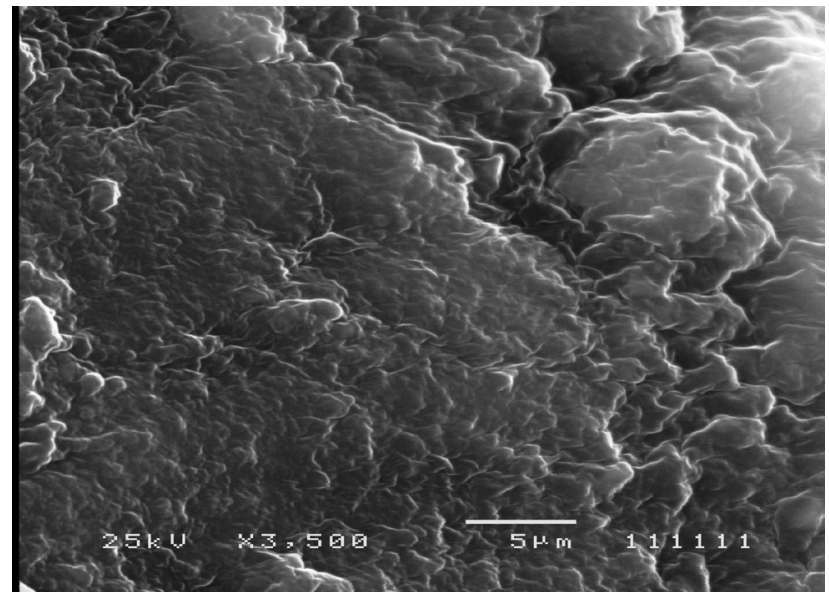

Fig.18: A scanning electron micrograph of a colon from a control rat (group I) showing velvety appearance of the mucosal surface (arrow). (SEM x 3500)

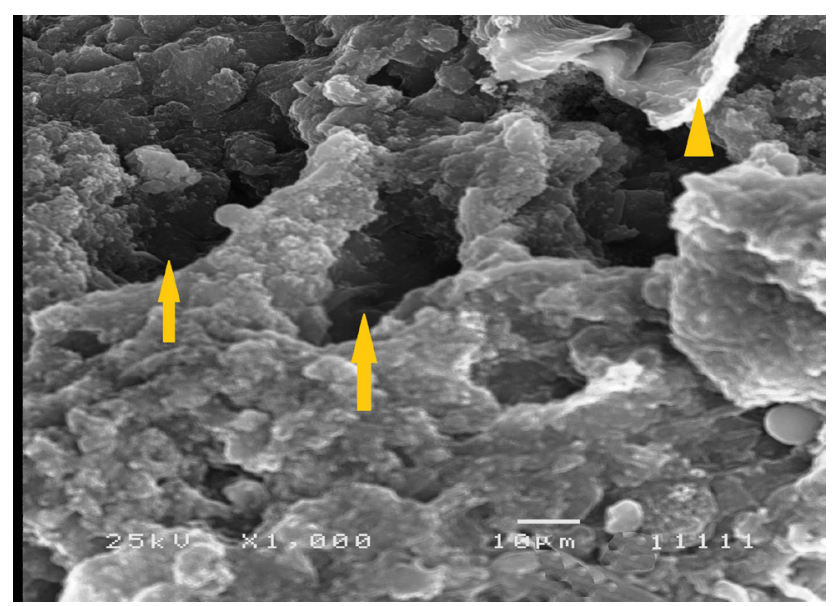

Fig. 19: A scanning electron micrograph of a colon from a diabetic rat (group III) showing widening of the openings of the crypts (arrows). Note the presence of mucous (arrowhead) secreted from the intestinal crypt. (SEM x 1000)

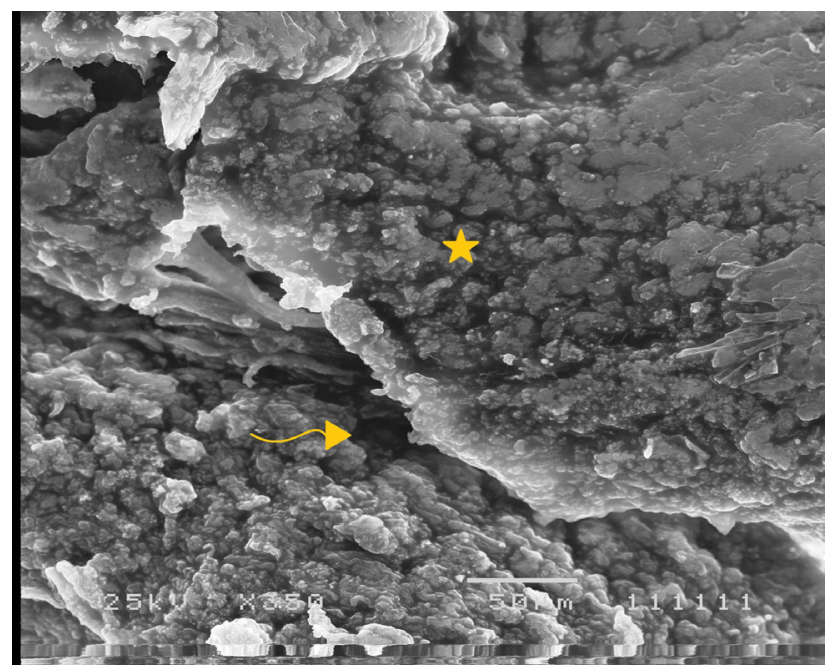

Fig. 20: A scanning electron micrograph of a colon from a diabetic rat (group III) showing a large fissure in the mucosa with appearance of the underlying connective tissue (curved arrow). Notice, desquamation of epithelial lining surface (asterisk). (SEM x 350)

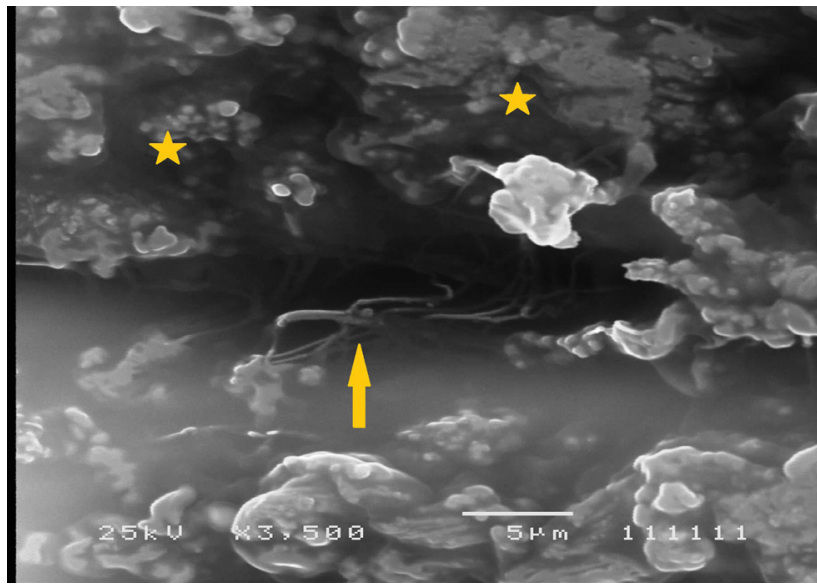

Fig. 21: A scanning electron micrograph of a colon from a diabetic rat (group III) showing exposed collagen fibers (arrow) in a mucosal fissure and ulceration with loss of surface lining epithelium (asterisk). (SEM x 3500)

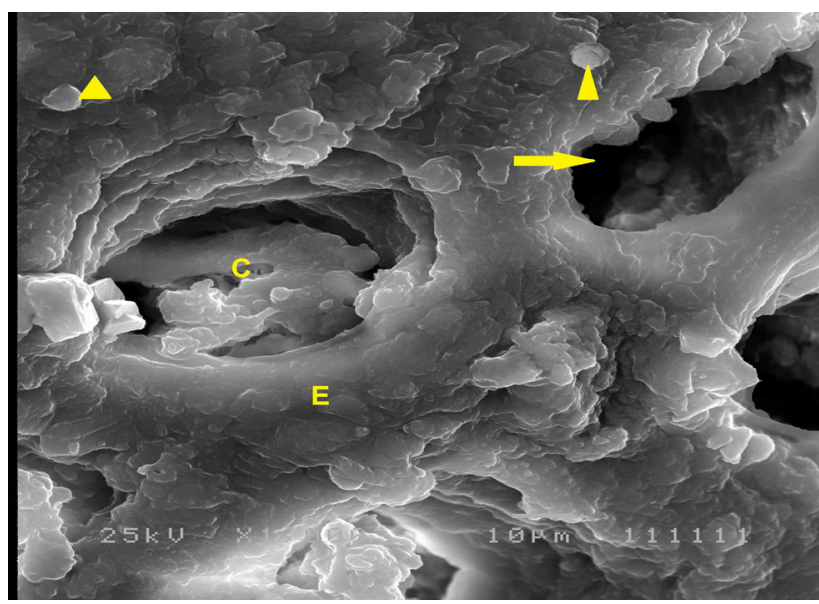

Fig. 22: A scanning electron micrograph of a colon from a diabetic ra treated with ocimumbasilum group (group IV) showing nearly normal shaped mucosal crypts with wide openings ( arrow ), intact mucosal surface (E) and goblet cells (arrowhead). Notice, the lumen of the crypt is obstructed with secreted mucus(C). (SEM x 1000)

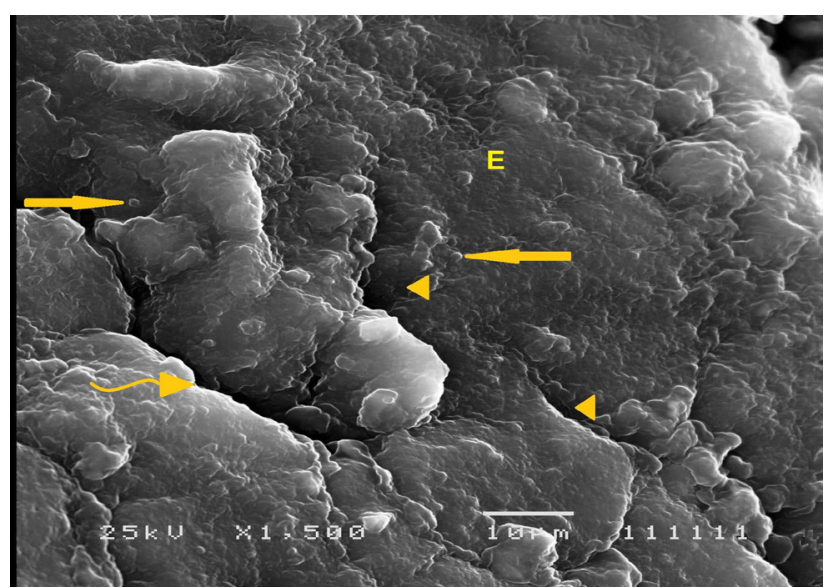

Fig. 23: A scanning electron micrograph of a colon from a diabetic rat treated with ocimumbasilicum group (group IV) showing normal shaped mucosal crypts openings (head arrow) with intact lining mucosal surface (E). Notice,goblet cells(arrows) and mucosal fold (curvedarrow). (SEM $\mathrm{x} 1500)$ 


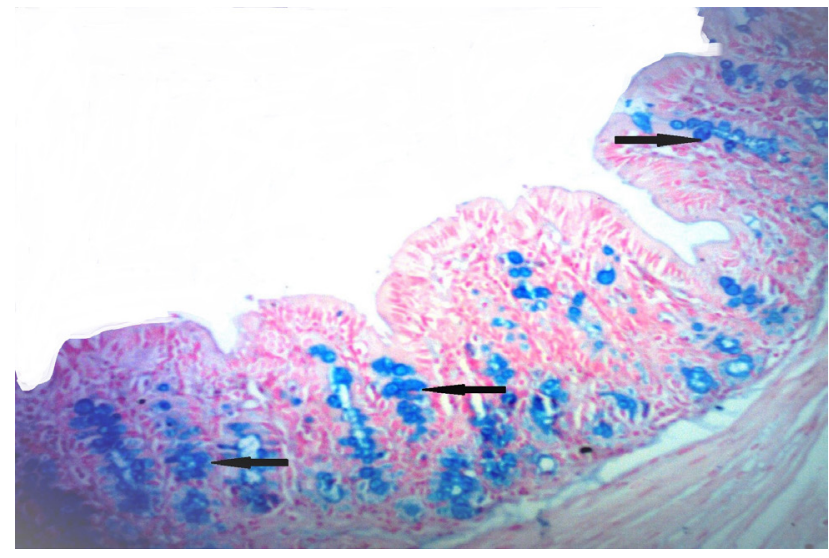

Fig. 24: A photomicrograph of a section of a colon from a control rat (group I) showing moderate positive reaction of goblet cells in the intestinal crypts (arrows). (Alcian blue x 200)

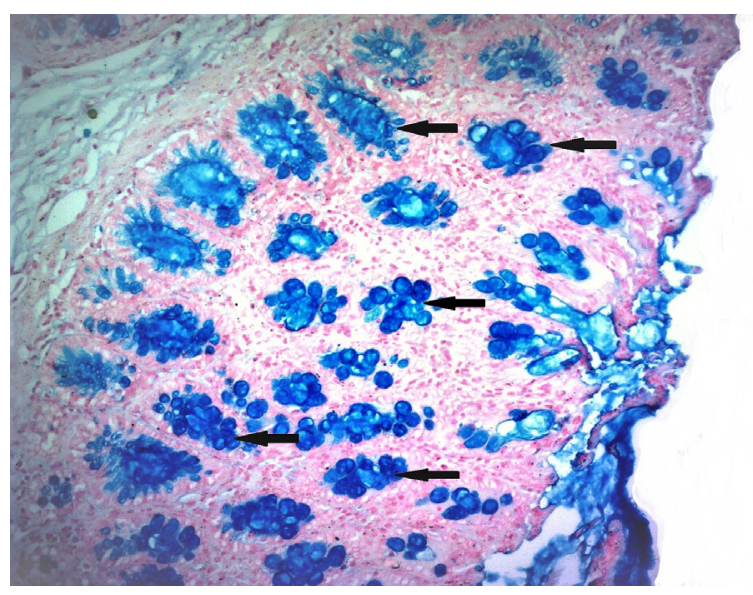

Fig. 25: A photomicrograph of a section of a colon from a diabeticrat (group III) showing strong positive reaction of goblet cells in the intestinal crypts (arrows). (Alcian blue x 200)

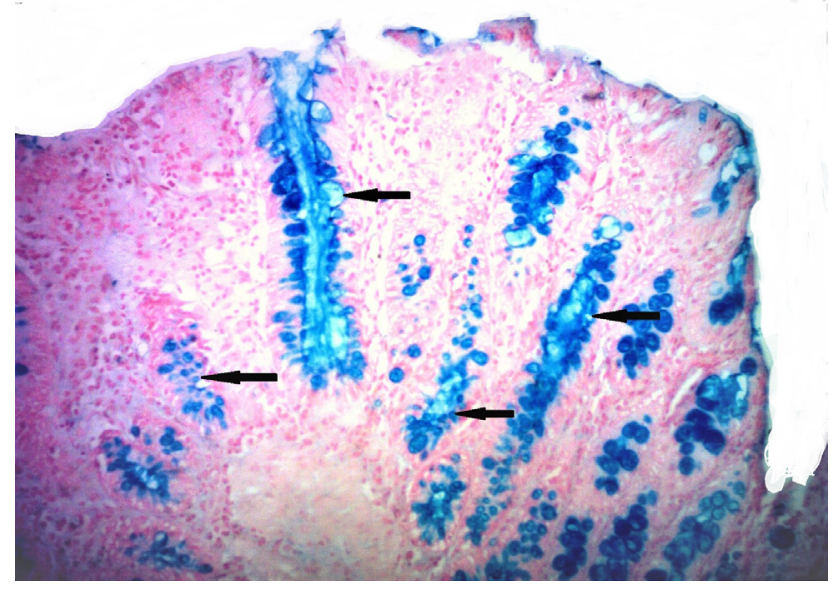

Fig. 26: A photomicrograph of a section of a colon from a diabetic rat treated with ocimumbasilicum group(group IV) showing moderate positive reaction of goblet cells oftheintestinalcrypts(arrows). (Alcian blue x 200)

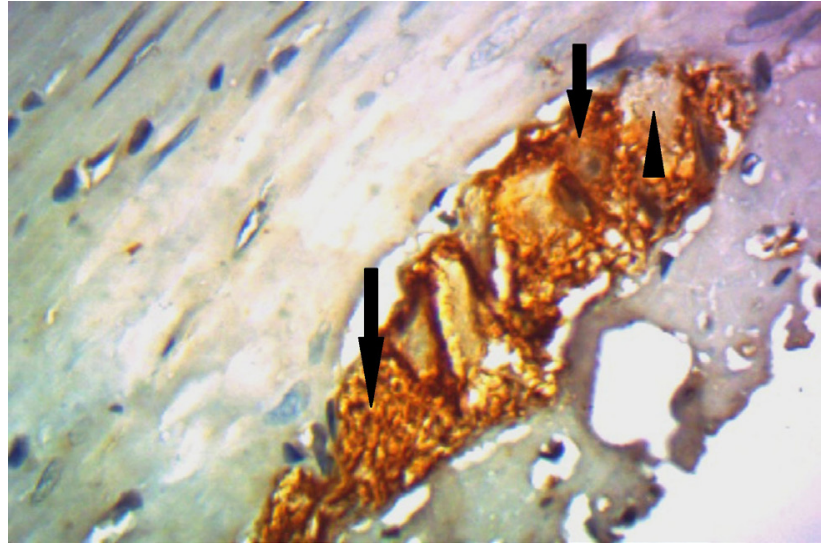

Fig. 27: A photomicrograph of a section of a colon from a control rat (group I) showinglarge myenteric plexus, contained numerous GFAP positive enteric glial cells which exhibited strong positive immunoreactions in their cytoplasm and their processes (arrows) and GFAP negative nerve cells (head arrow). (GFAP x 1000)

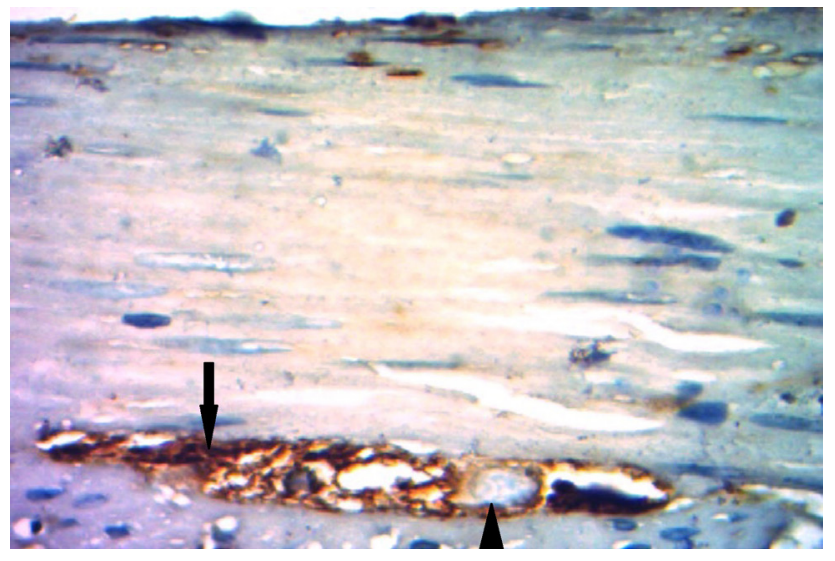

Fig. 28: A photomicrograph of a section of a colon from a diabeticrat (group III) showing small sized myenteric plexus with few GFAP positive enteric glial cells which have weak positive immunoreactions(arrow) surrounding immune-negative nerve cells (arrow head). (GFAP x 1000)

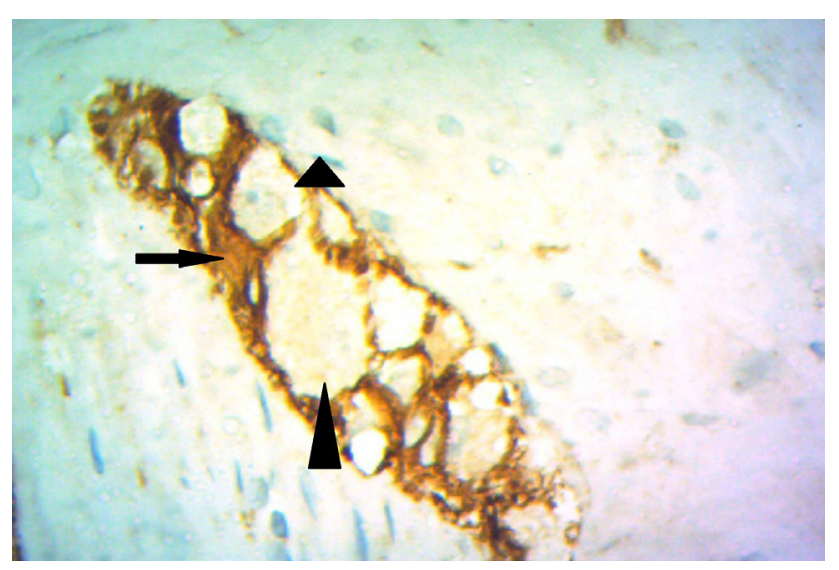

Fig. 29: A photomicrograph of a section of a colon from adiabetic rat treated with ocimumbasilicum group(group IV) showing moderate positive GFAP immune- reaction in enteric glial cells (arrow)surrounding immune-negative nerve cells (arrowhead). (GFAP x 1000) 


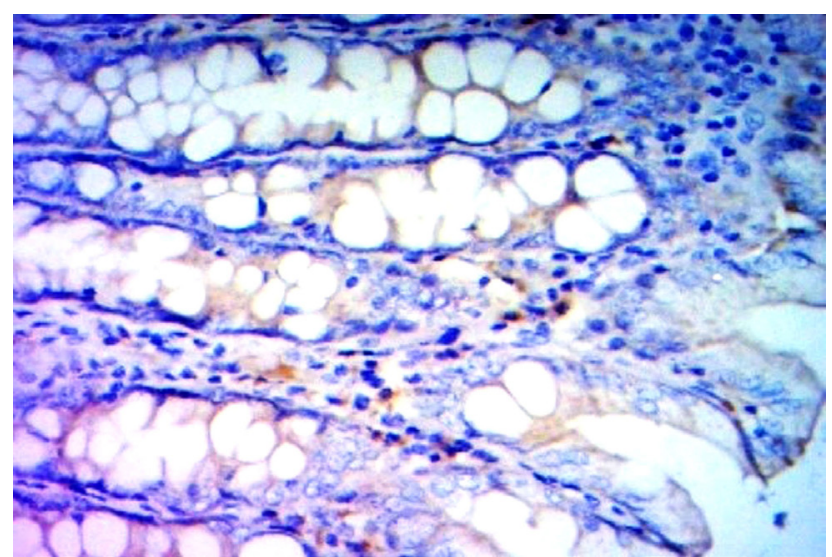

Fig. 30: A photomicrograph of a section of a colon from a control rat (group I) showing weak positive immunoreactions for iNOS in the mucosa. (iNOS x 400)

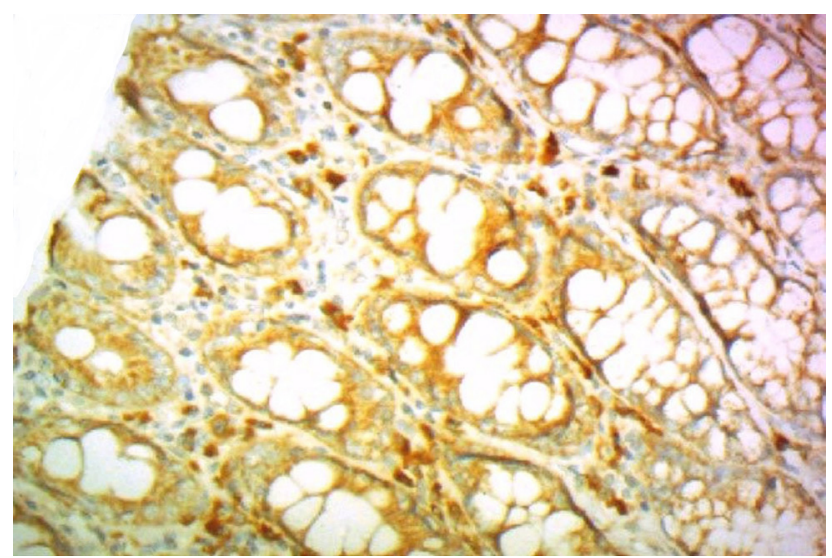

Fig. 31: A photomicrograph of a section of the colon from a diabetic rat (group III) showing a strong positive immunoreaction for iNOS in the mucosa. (iNOS x400)

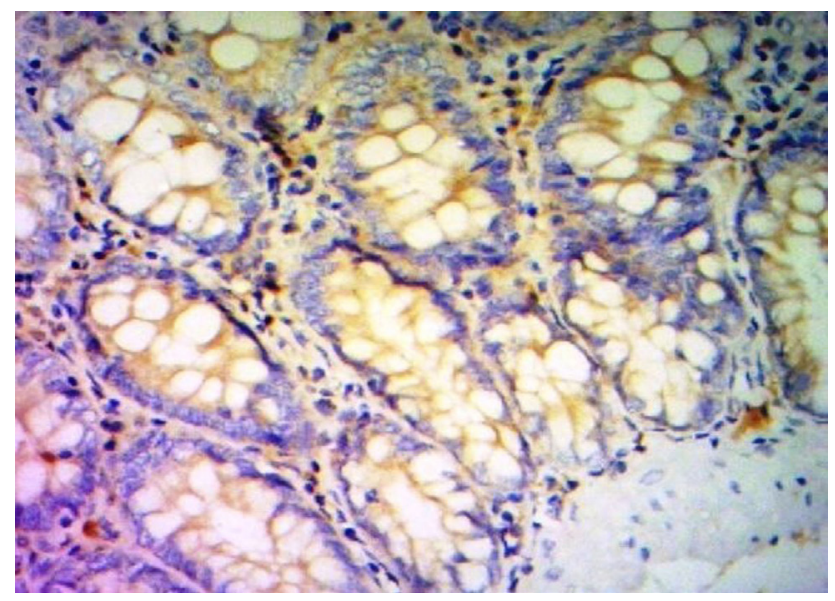

Fig. 32: A photomicrograph of a section of a colon from a diabetic rat treated with ocimumbasilicum group(group IV) showing moderate positive immmunoreaction for iNOS in the mucosa. (iNOS x 400)
Table 1: Means of fasting blood glucose level (mg/dl ) of various experimental groups

\begin{tabular}{lc}
\hline \multicolumn{1}{c}{ Experimental groups } & $\begin{array}{c}\text { Blood glucose level (mg/dl) } \\
\mathrm{x}^{-} \pm \mathrm{SD}\end{array}$ \\
\hline Control group (group I) & $120.9 \pm 7.2$ \\
O. basilicum group (group II) & $118.1 \pm 7.00$ \\
Diabetic group (group III) & $233.8 \pm 17.8^{* *}$ \\
Diabetic + O. basilicum Group (IV) & $133.5 \pm 6.1^{* *}$ \\
\hline $\mathrm{x}^{-}=$the mean value. SD $=$the standard deviation. \\
$* *$ Highly significant from the control group $(p<0.001)$.
\end{tabular}

Table 2: Effect of diabetes on the antioxidant enzymes activities and the level of lipid peroxidation in the plasma of all groups of rats

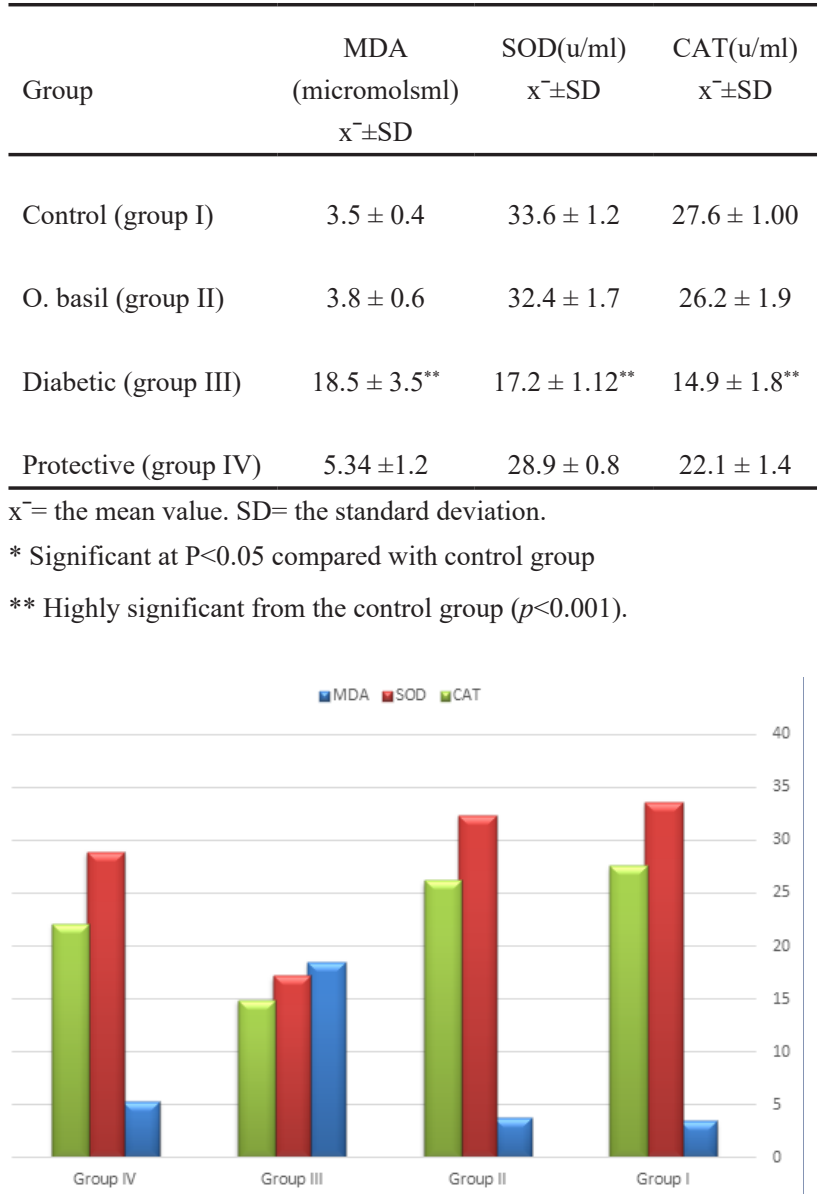

Histogram 1: The Mean MDA, SOD and CAT levels in experimental different groups 
Table 3: Means and standard deviationsof the depth of intestinal crypts\&number of goblet cells per field at magnification of 400xof various experimental groups

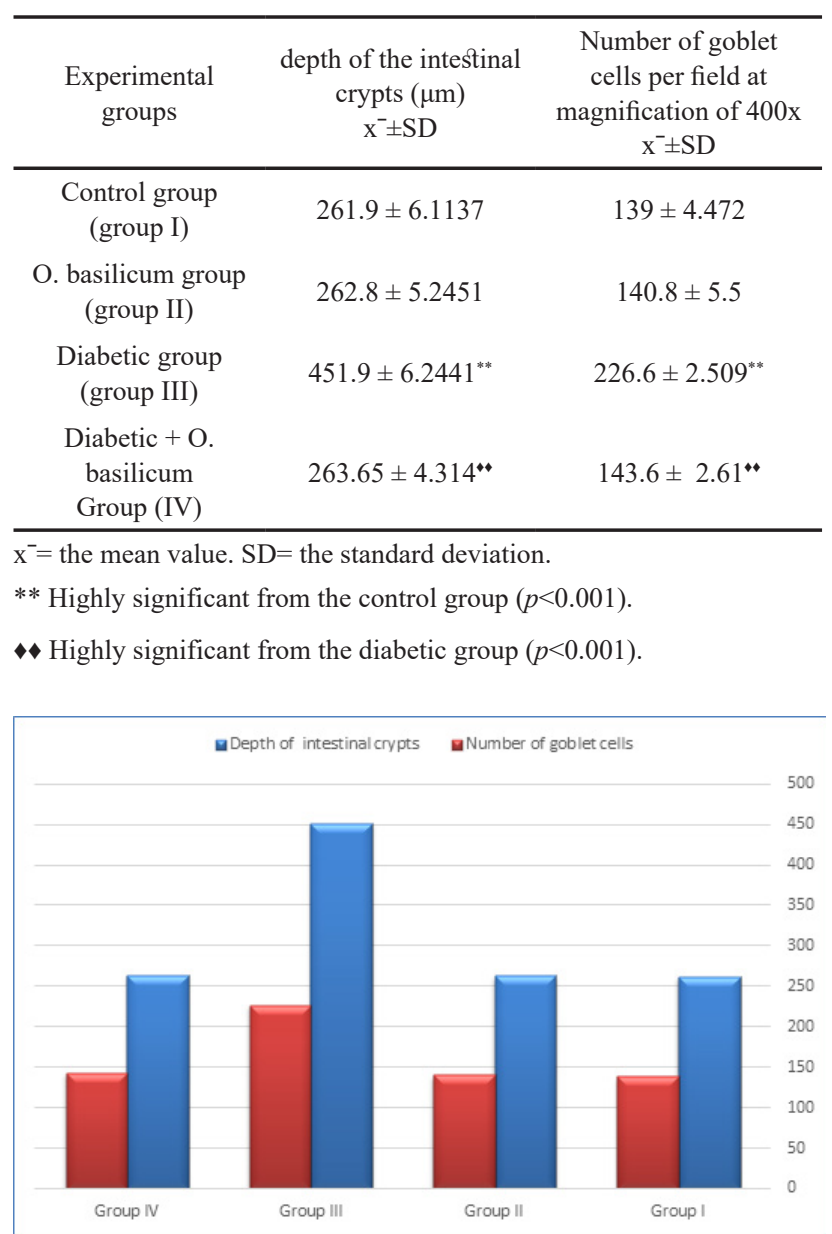

Histogram 2: The mean of the depth of intestinal crypts and the number of goblet cells in different groups

Table 4: Means and standard deviations (SD) of the intensity of iNOS immune reaction \& the intensity of GFAPimmune reaction of various experimental groups

\begin{tabular}{lcc}
\hline Experimental groups & $\begin{array}{c}\text { Intensity of iNOS } \\
\text { immune reaction } \\
\mathrm{x}^{-} \pm \mathrm{SD}\end{array}$ & $\begin{array}{c}\text { Intensity of GFAP } \\
\text { immune reaction } \\
\mathrm{x}^{-} \pm \mathrm{SD}\end{array}$ \\
\hline $\begin{array}{l}\text { Control group } \\
\text { (group I) }\end{array}$ & $4.096 \pm 1.012$ & $48.816 \pm 6.832$ \\
$\begin{array}{l}\text { O. basilicum } \\
\text { group(group II) }\end{array}$ & $3.991 \pm 1.347$ & $50.376 \pm 3.931$ \\
$\begin{array}{l}\text { Diabetic group } \\
\text { (group III) }\end{array}$ & $15.96 \pm 0.824^{* *}$ & $6.342 \pm 1.099^{* *}$ \\
$\begin{array}{l}\text { Diabetic }+ \text { O. } \\
\text { basilicum } \\
\text { Group (IV) }\end{array}$ & $5.591 \pm 1.025^{* *}$ & $42.502 \pm 2.425^{* *}$ \\
\hline
\end{tabular}

$\mathrm{x}^{-}=$the mean value. $\mathrm{SD}=$ the standard deviation.

** Highly significant from the control group $(p<0.001)$.

$\leftrightarrow$ Highly significant from the diabetic group $(p<0.001)$.

\section{DISCUSSION}

In this study,experimental diabetes was induced effectively with alloxan, proved by hyperglycemia. The typical features of diabeteslike polydipsia, polyphagia and polyuriawere observedduring the animal's daily behaviorof the diabetic animals (group III) when compared with the animals ofgroups (I and II). The diabetic animals that received $\mathrm{O}$. basilicum supplementation (group IV) exhibited a significant reduction in glycaemia, compared with group III (diabetic group). This indicates a positive impact of this plant on blood glucose levels. This was in accordance with the results of ${ }^{[23]}$ who concluded thatEugenol is the most important bioactive compound for reducing blood glucose level. Also, ${ }^{[24]}$ found that the leaf extracts of $\mathrm{O}$. basilicum have anti-hyperglycemic effects by increasing the secretion of insulin from isolated islets. In addition, ${ }^{[25]}$ explained that the decrease in blood glucose level in alloxan diabetic rats treated with $\mathrm{O}$. basilicum was via $\alpha$-glucosidase and $\alpha$-amylase inhibiting activities.

In the current study, the diabetic group showed a significantincrease in plasma level of MDA which indicates elevation of lipidperoxidation and oxidative stress. Also, diabetesdecreased the activities of SODand CAT significantly which are enzymeswith the most important defense mechanism against oxidative stress induced by free radicals. The elevation in thelevel of lipidperoxidation in the colonwas previously recorded by other studies on different tissues ${ }^{[26]}$. Administration of $\mathrm{O}$. basilicum to diabetic rats diminished significantlythelevels of MDAand elevated the level of antioxidant enzymesin the plasma. This was in accordance with Sakr and AL-Amoudi ${ }^{[27]}$ who verified that $\mathrm{O}$. basilicum reduced oxidative stress markers and had a strong antioxidant role.

In this study, the diabetic colon showed disturbed crypts with widening of their lumens, loss of surface epithelium $\&$ cellular infiltrations in the corium. Decrease in the size of the myenteric plexuses with atrophy of their EGCs and neurons were also observed. These changes were suggested as a result of an increase in lipid peroxidation with a decrease of antioxidants that was found in the biochemical results of this work. It is well-known that the majorfactor in production of free radicals, development of oxidative stress and decrease of endogenous antioxidant enzymes was hyperglycemia ${ }^{[28]}$. Consequently, the excess free radicals damage the cell membrane phospholipids and other cell components through lipid peroxidation ${ }^{[29]}$. Atrophy ofthe myenteric plexuses and their nerve cells of the colon of this group, led to contracted colonic wall in some areas resulting in fecal impaction in these contracted areas and subsequent enterocolitis, necrosis, ulceration and disturbance of the wall of the colon ${ }^{[30]}$.

Administration of $\mathrm{O}$. basilicum improved the histological changes in the diabetic animals. Actually, other studies on humans \& animal models have demonstrated that aqueous extract of $\mathrm{O}$. basilicum had the ability to scavenge the free radicals which subsequently protected organs against harmful effects of diabetes. The nearly normal appearance of the colonic tissues shown by histological study supported this interpretation ${ }^{[31]}$. Many previous studies confirmed that plants with phenolic compounds 
like O. Basilicum had anti-hyperglycemic, anti-oxidative and anti-lipidemic activities protecting against diabetes ${ }^{[32]}$.

In the present study, the diabetic colon showed an apparent increase in goblet cells with fusion of some of them that showed by strong positive Alcian blue reaction in these cells. These results were confirmed by scanning electron microscopic results which revealed distended goblet cells with excess mucous secreted from the intestinal crypts. Excess mucous secretion may be due to scavenging free radicals property of $\mathrm{O}$. basilicum, which prevents the free radical accumulation, which causes damage and ulceration of mucosa ${ }^{[33]}$

Increase in goblet cells and their mucus secretion may bea trial to develop abetter defense mechanism of intestine in stress conditions ${ }^{[34]}$. This was in accordance with Rafael et al. ${ }^{[35]}$ who observed larger quantities of Golgi apparatus in sedentary diabetic rats, referring to a higher rate of synthesis and secretion of mucus. Also, Ettarh and Carr ${ }^{[36]}$ observed that rats with acute diabetes showed a larger number of goblet cells intheir intestinal villi. However, administration of $\mathrm{O}$. basilicum to diabetic rats revealed remarkable effect on goblet cells by its antioxidant activity, causing return of its mucous contents to normal as proved by the moderately positive Alcian blue reaction of goblet cells of this group.

In the current study, the colon of diabetic rats showed a statistically significant increase in the mean crypt depth when compared with the $\mathrm{O}$. basilicum treated group ${ }^{[37]}$ supported this result, who found that rats of diabetic group had deeper crypts than those of non-diabetic group. In addition, ${ }^{[38]}$ observed wider crypts of Lieberkuhn in the mid-colon of mice suffering from diabetes. The increase in depth of crypts may be explained by increased gastrointestinal contents due to polyphagia and polydepsia which is compensated by the increase in the surface absorption of the diabetic colon.

In the present study, the Mallory stained sections showed an apparent increase in the collagen fibers in diabetic rats when compared to the non-diabetic control rats. It is in consistent with what is known about fibrosis as a common pathological response to tissue insults such as hyperglycemia, dyslipidemia, and hypertension.The chronic hyperglycemia can cause tissue injury, leading to the development of fibrosis with predominant extracellular matrix (ECM) accumulation. ThisECM accumulationcan be due to increased synthesis of matrix proteins and/or an inhibition of ECM degradation.It was established that the hyperglycemia can work through both metabolic and hemodynamic pathways to change ECM turnover ${ }^{[39]}$.Also, hyperglycemia is responsible for the presence of high levels of non-enzymatically produced advanced glycation end-products which are able to stimulate directly the production of $\mathrm{ECM}^{[40]}$. Furthermore, ${ }^{[41]}$ observed abnormal changes in the metabolism of ECM in diabetic patients with diarrhea. Such defects in the extracellular matrix 'metabolism may be also the cause of the abnormal changes noticed in the corium of mucosa and submucosa in this study. However, administration of $\mathrm{O}$. basilicum to diabetic rats showed remarkable reduction in the collagen 'content in the submucosa of colon when compared with that of the diabetic colon. This may be due to strong radical scavenging and antioxidant properties of $\mathrm{O}$. basilicum since the oxidant/antioxidant imbalance is a key step in the development of fibrosisand also, owing to its phenolic and flavonoid contents ${ }^{[42]}$.

In this study, immunostaining results revealed that the diabetes caused a significant reduction in the intensity of GFAP positive enteric glial cells (EGCs). This was in accordance with ${ }^{[43]}$ who proved that four weeks after diabetes induction, there was a reduction in the number and intensity of staining of GFAP positive EGCs cells at, which was more prominent after 12 weeks in rat colon. In addition, ${ }^{[44]}$ found that the mean of GFAP immunepositive EGCs was greatly reduced in diabetes and showed marked improvement after vitamin E supplementation. However, administration of $\mathrm{O}$. basilicum to the diabetic rats showed a marked increase in the number and intensity of GFAP staining positive EGCs. Parallel with this result, the previous studies demonstrated that $\mathrm{O}$. basilicum exert a neuroprotective effect that was attributed to its content of flavonoid, tannin and phenolic compounds which are free radical scavengers ${ }^{[45]}$. In addition, ${ }^{[46]}$ found that $O$. basilicum significantly increased the GFAP-positive cells and number of astrocytes of cerebral cortex of mice exposed to chronic unpredictable mild stress.

Colonic sections from diabetic group revealed a strong positive immmunostaining for iNOS. This was in agreement with Basilia et al. ${ }^{[47]}$ who reported that iNOS staining was intense inthe inflamed rat colon mainly in the damaged tissue and in the infiltrated inflammatory cells. Many clinical studies showed increased iNOS activity and elevated levels of nitrite in rectal dialysates and in colonic biopsies of patientswith ulcerative colitis or Crohn's diseases ${ }^{[48]}$. Other studies conducted on animal models,showed that high glucose concentrations increase the inflammatory cytokines and levels of iNOS in rat kidney ${ }^{[49]}$. However, treatment with $\mathrm{O}$. basilicum reduced iNOS activity in the diabetic rats. These results were supported by the previous works of Mbaoji et al. ${ }^{[24]}$ and Miraj and Kiani ${ }^{[25]}$ who showed that aqueous extract of O. basilicum has in-vitro anti-hyperglycemic and antiinflammatory activities. Other researchers demonstrated that $\mathrm{O}$. basilicum reduces the activity of iNOS either directly through inhibition of iNOS expression or indirectly through the reduction of influx of inflammatory cells expressing iNOS into the diabetic colon ${ }^{[47]}$.

From all the mentioned data and results, it is concluded that administration of $\mathrm{O}$. basilicum in rats with diabetes mellitus could improve the histological, biochemical and morphometric abnormalities of the colon. It also has a protective effect on the myenteric (Aeurbach's) plexus. Therefore, O. basilicum could be prescribed for diabetic patients to improve the colonic changes and the 
neurological manifestations.Further investigations will be done to elucidate the potential usefulness of this plant as a source of protective agents against the diabetic colonic damage in clinical trials.

\section{CONFLICTS OF INTEREST}

There are no conflicts of interest.

\section{REFERENCES}

1. PunthakeeZ, GoldenbergR, Katz, (2018): Definition, Classification and Diagnosis of Diabetes, Prediabetes and Metabolic Syndrome. Can J Diabetes 42 : S10-S15

2. Sabban ENC, Puchulu FM \&Cusi K (2018):Dermatology and Diabetes, 1st edition. Springer science press, chapter 2: 7 .

3. Alberti,K.G.M., Zimmet,P.(2013): Epidemiology: Global burden of disease-where does diabetes mellitus fit in? Nature Reviews Endocrinology, 9, 258-260.http://dx.doi.org/10.1038/nrendo.54

4. Ciobanu L, Dumitrascu DL(2011): Gastrointestinal motility disorders in endocrine diseases. PolArchMedWewn ; 121:1219-136.

5. Feldman EL, Nave KA, Troels S, David LH, Bennett E (2017): New Horizons in Diabetic NeuropathyMechanisms, Bioenergetics, and Pain .Neuron 93, March 22, 1296- 1313.

6. Maceachern SJ, Patel BA, Mckay DM, Sharkey KA. (2011): Nitric oxide regulation of colonic epithelial ion transport : a novel role for enteric glia in the myenteric plexus. J Physiol ; 589: 3333-3348.

7. Dhanesha N, Joharapurkar A, Shah G, Dhote V, Kshirsagar S, Bahekar R, Jain M. (2012) Exendin-4 activatesglucokinase. J Diabetes;in press: doi: 10.1111/j.1753-0407.00193.x.

8. Ravindran PN (2017):The Encyclopedia of Herbs and Spices, $1^{\text {st }}$ edition.CABI,Chapter 200: 954957.

9. Ambrose DCP, ManickavasaganA ,Naik R (2016):Leafy Medicinal Herbs: Botany, Chemistry, Postharvest Technology and Uses, $1^{\text {st }}$ edition. CABI,Chapter 3: 27-40.

10. Ezeani C, Ezenyi I, Okoye T, and Charles OkoliC (2017):Ocimumbasilicum extract exhibits antidiabetic effects via inhibition of hepatic glucose mobilization and carbohydrate metabolizing enzymes. J IntercultEthnopharmacol; 6(1): 22-28.

11. Naidu JR, Gunjan M, Chen Y, SasidharanN (2016) :Evaluation of in vitrocytotoxic activity of ocimumbasilicum and menthaspicata extracts. Asian J Pharm Clin Res, Vol 9(3):131-134.
12. Sholichah WAR (2017): Phytochemical screening and antioxidant activity of ethanolic extract and ethyl acetate fraction from basil leaf (Ocimumbasilicum L.) by DPPH radical scavenging method. IOP Conf. Series: Materials Science and Engineering 259,012008 doi:10.1088/1757-899X/259/1/012008, IPCUAD2017 IOP Publishing.

13. Rashidian A, Roohi P, Mehrzadi S, Ghannadi AR and Minaiyan M (2016): Protective Effect of OcimumBasilicum Essential Oil Against Acetic Acid- Induced Colitis in Rats. Journal of evidence based complementary \&alternative medicine vol. 21(4) 36-41.

14. Ighodaro OM, Adeosun AM \&Akinloyeb OA (2018):Alloxan-induced diabetes, a common model for evaluating the glycemic-control potential of therapeutic compounds and plants extracts in experimental studies.MedicinaVol 53, Issue 6, 2017, Pages 365-37.

15. Anoopkumar-Dukie S, Walker RB, Daya S (2001) A sensitive and reliable method for the detection of lipid peroxidation in biological tissuesJ. Pharm. Pharmacol. 53, pp. 263-266CrossRefView Record inScopus.

16. Kakkar P, Das B, Viswanathan PN (1984): A modifiedspectrophotometeric assay of superoxide dismutase Indian J. Biochem. Biophys., 21 , pp. 130-132View Record in Scopus.

17. Aebi HE: Catalase. In: H.U. Bergmeyer (ed). Methods in EnzymaticAnalysis.VerlagChemie, Berlin, 1983, pp 278-282.

18. Bancroft, J.D, and Layton, C (2010) : Theory and practice of histological technique $7^{\text {th }}$ ed., London: Churchill Livingstone. Pp. 173-214.

19. Kiernan, J.A. (2015): Histological and histochemical methods; Theory and practice. 5thed. P.238-390.

20. Bancroft Jd and Gamble M. (2013): Theory and practice of histological techniques. 7th ed. 2013, Churchill Livingstone/Elsevier, Oxford:173-179,363-39.

21. Miller MJS, Thompson JH, Zhang X-J, SadowskaKrowicka H, Kakkis, JL, MunshiUK, Sandoval M, Rossi JL, Eloby-Childress S, Beckman JS, Ye YZ, RodiCP,Manning PT, Currie MG and Clark DA (1995): Role of inducible nitric oxide synthase expression and peroxynitrite formation in guinea pig ileitis.Gastroenterology 109:1475-1483.

22. Peat J and Barton B(2005): Medical statistics. A Guid to data analysis and critical appraisal.First Edition.Wiley-Blackwell.113-19. 
23. Kadan S, Saad B, SassonY, Zaid H (2016) :In vitro evaluation of anti-diabetic activity and cytotoxicity of chemically analysed Ocimumbasilicum extracts Food Chem, 196 , pp. 1066-1074.

24. Mbaoji FN, Okoli CO, Ezike AC (2014): Preliminary antihyperglycemic activity-guided studies on the leaf extract and fractions of Ocimumbasilicum LJ Chem Pharm Res, 6 (4) pp. 575-580.

25. Miraj S, Kiani S (2016) : Study of pharmacological effect of Ocimumbasilicum: a review Der Pharm Lett, 8 (9) , pp. 276-280

26. Kakkar, R., Kalra, J., Mantha, S. V., \& Prasad, K. (1995). Lipidperoxidation and activity of antioxidant enzymes in diabeticrats.Molecular and Cellular Biochemistry, 151, 113-119.

27. Sakr, SA; AL-Amoudi, WM(2012): Effect of leave extract of Ocimumbasilicumondeltamethrin induced nephrotoxicity and oxidative stress in albino rats. J. Appl. Pharm. Sci., v.2, n.5.

28. Bonnefont RD (2002): Glucose and reactive oxygen species. CurrOpinClinNutrMetabCare ; 5: $561-568$.

29. Shirpoor A, Khadem Ansari MH , Salami S , GhaderiPakdel F , Rasmi Y (2007): Effect of vitamin $\mathrm{A}$ on oxidative stress status in small intestine of diabetic rat. World J Gastroenterol;13: 4340- 4344.

30. Kumar V, Cotran RS, Robbins SL (2003): Robbin's basic pathology. $7^{\text {th }}$ ed. Philadelphia: W.B. Saunders CO. ,564.

31. Jayasinghe, C, Gotoh, N, Aoki, T, Wada, S.(2003): Phenolics composition and antioxidant activity of sweet basil (OcimumbasilicumL.). J. Agric. Food Chem., v.51, n. 15, 4442-49.

32. Camila M G, Raul O de S, Paula F, Maria F, Moura L, Jonathaline A D, Aline A B, Margareth LA(2017:Evaluation of basil extract (OcimumbasilicumL.) on oxidative, anti-genotoxic and anti-inflammatory effects in human leukocytes cell cultures exposed to challenging agents Braz. J. Pharm. Sci. ;53(1):e15098.

33. Brownlee M. (2001): Biochemistry and molecular cell biology of diabetic complications. Nature ; 414: 813 -820

34. Ross MH ,Pawlina W (2011): Histology A Text and Atlas with correlated cell and molecular biology . $6^{\text {th }}$ edition. 586- 601.

35. Rafael N R, Alexandre C, Rodrigo A B, Ricardo J G, Flavio H. (2012): Morphological Analysis of Colon Goblet Cells and Submucosa in Type I Diabetic Rats Submitted to Physical Training. Microscopy Research and Technique; 75:821-828.
36. Ettarh RR, Carr KE (1997): A morphological study of the enteric mucosalepithelium in the streprozotocin-diabetic mouse.LifeSci, 61:1851-1858.

37. de Freitas P, Natali MRM, Pereira RVF, Neto MHM , Zanoni JN (2008): Myenteric neurons and intestinal mucosa ofdiabetic rats after ascorbic acid supplementation. World J Gastroenterol ; 14: 6518- 6524.

38. Domenech A ,Pasquinelli G, de Giorgio R, Gori A, Bosch F, Pumarola M , Jimenez M (2011): Morphological changes underlying intestinal dysmotility in diabetic RIPP-I-hIFNB transgenic mice. Int J ExpPathol ; 92: 400 - 412.

39. Camelia R Ban and Stephen M Twigg (2008): Fibrosis in diabetes complications: Pathogenic mechanisms and circulating and urinary markers. Vasc Health Risk Manag. Jun; 4(3): 575-596.

40. Goldin A, Beckman JA, Schmidt AM, Creager MA(2006) : Advanced glycation end products: sparking the development of diabetic vascular injury. Circulation. 2006;114:597-605.

41. Unal A, Guven K, Yurci A, Torun E, Gursoy S, Baskol M, OzturkF,Arsav V. (2008): Is increased colon subepithelial collagen layer thicknessin diabetic patients related to collagenous colitis? An immunohistochemicalstudy.Pathol Res Pract 204:537-544.

42. Hanan A. Ogaly,1, Nadia A. Eltablawy, Adel M. El-Behairy,1 Hatim El-Hindi,1 andReham M. Abd-Elsalam (2015): Hepatocyte Growth Factor Mediates the Antifibrogenic Action of Ocimumbacilicum Essential Oil against $\mathrm{CCl}$ Induced Liver Fibrosis in Rats. Molecules. Aug; 20(8): 13518-13535.

43. Liu W, Yue W, Wu R (2010): Effects of diabetes on expression of glial fibrillary acidic protein and neurotrophins in rat colon. Autonomic Neurosci Basic Clin ; 154: 79- 83.

44. Elmansy RA, Atia GM, Abd- El Rahman ES (2013): Effect of vitamin E supplementation on the colon of diabetic rats with special emphasis on the myenteric plexus: an immunohistochemical and scanning electron microscopic study. Egypt J Histol 36: 781-791.

45. Bora KS, Arora S, Shri R (2011): Role of OcimumbasilicumL. in prevention of ischemia and reperfusioninducedcerebral damage, and motor dysfunctions inmice brain. J. Ethnopharmacol. 137: $1360-1365$.

46. Ayuob NN, Alaa El-Din LF, Ahmed A ElMansy, Soad A (2017): Can Ocimumbasilicum relieve chronic unpredictable mild stressinduceddepression in mice? Experimental and Molecular Pathology 103 :153-161. 
47. Basilia Z, Salvatore C, Andrew LS (1998): Mercaptoethylguanidine, a Combined Inhibitor of Nitric Oxide Synthase and Peroxynitrite Scavenger, ReducesTrinitrobenzene Sulfonic Acid-Induced Colonic Damage in Rats.

48. Ikeda I, Kasajima T, Ishiyama S, Shimojo T, Takeo Y, Nishikawa T, Kameoka S, Hiroe M and Mitsunaga A (1997): Distribution of inducible nitric oxide synthase in ulcerative colitis. Am J Gastroenterol 92:1339-1341.

49. Huseyin A, Vildan BC, Buket K, Fatih O ,ŞirinB,TurkerC,Saadet O (2012): Dysregulation of nitric oxide synthase activity and $\mathrm{Bcl}-2$ andcaspase-3 gene expressions in renal tissue ofstreptozotocin-induced diabetic ratsTurk $\mathrm{J}$ Med Sci; 42 (5): 830-838. 


\title{
الملخص العربى
}

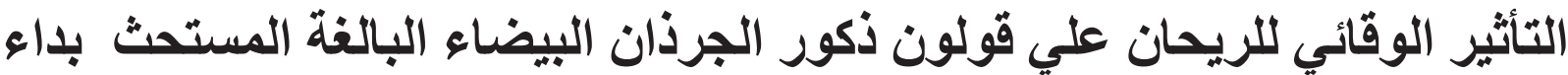

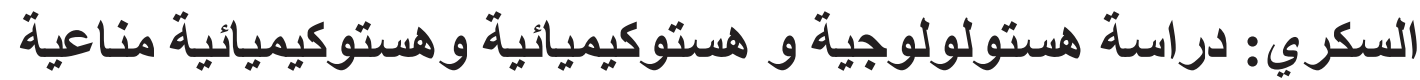

\author{
مها السيا سليمان، اميرة فهمي علي، نادية سعيد بلوي خير، ريهام عبد الله محمود \\ قسم الهستولوجيا وبيولوجيا الخلية كلية الطب -جامعة المنوفية
}

المقدمة: مرض السكري هو واحد من أكبر أمر اض الغدد الصماءالتى تصيب البنكرياس. وهو يتميز بارتفاع السكر في الدم واختلال الأيض الغذائى للاهون و الكربوهيدرات والبروتينات التي تتتج عن نقص الأنسولين أو خلل في عمله أو كليهما. و يعتبر حاليا مرض السكرى واحد من المشاكل الصحية الرئيسية في العالم. يعتبر الريحان واحدًا من أكثر النباتات العشبية انتشارًا في العالم. حيث أنه يحتوي على عدد كبير من المواد الكيميائية النباتية التي لها فوائد صحية و غذائية كثيرة. وينتمى الريحان الى عائلة النباتات الثفوية ويتمبز بأن لله نشاط خافض للضغط ،و مضاد للأكسدة

و مضاد للسرطان.

الهـف من البحث: تقييم التأثثر الوقائي المحتمل للريحان على القولون في ذكور الجرذان البيضاء البالغة المصابة بمرض السكرى. طرق ومواد البحث: تم استخدام سنين من ذكور الجرذان البيضاءالبالغة في هذه الدراسة.وقد تم تقسيم الجرذان إلى أربع مجموعات كالأتى: المجموعة الأولى (المجموعة الضابطة) ، المجموعة الثانية (المجموعة المعالجة بالريحان) ، المجموعة الثالثة (المجموعة المصابة بمرض السكري) و المجموعة الر ابعة (المجموعة المصابة بمرض السكري و المعالجة بالريحان). وفى نهاية الفترة المحددة للار اسة ، تم تخدير الحيو انات من جميع المجمو عات ونم اخذ عينات دم للار اسة البيوكيميائية كما تم جمع عينات من القولون وتجهيز ها للفحص بالمجهر الضوئى والمجهر الإلكترونى الماسح. النتائج: أظهرت الدر اسة ان قولون الجرذان المصابة بالسكري تتميزبزيادة كبيرة في عمق الخبايا المعوية وعدد الخلايا الكأسية مع تغير ات بيو كيميائية ونسيجية ومورفومترية ملحوظة مثل زيادة مستو يالمالو نديالديهيد في البلازما , وتساقط الغثاء المخاطي السطحي و وضمور وصغر حجم الضفيرة العصبية المعوية. كما أظهرت الدراسة ان إعطاء الريحان للجرذان المصابة بداء السكري قد أدى الى تحسن ملحوظ في هذه التغيرات النسيجية والبيوكيميائية والمورفومترية. الخلاصة: الريحان المعطى للجرذان المصابة بداء السكري لله تأثثر وقائى على التغيرات النسيجية و البيوكيميائية و المورفومترية للقولون كما ان له أيضا تأثثير وقائي على الضفيرة العصبية المعوية. 